\title{
Evaluation and prediction of nitrogen use efficiency and outputs in faeces and urine in beef cattle
}

Article

Accepted Version

Creative Commons: Attribution-Noncommercial-No Derivative Works 4.0

Angelidis, A., Crompton, L., Misselbrook, T., Yan, T., Reynolds, C. and Stergiadis, S. (2019) Evaluation and prediction of nitrogen use efficiency and outputs in faeces and urine in beef cattle. Agriculture, Ecosystems and Environment, 280. pp. 115. ISSN 0167-8809 doi:

https://doi.org/10.1016/j.agee.2019.04.013 Available at https://centaur.reading.ac.uk/83256/

It is advisable to refer to the publisher's version if you intend to cite from the work. See Guidance on citing.

To link to this article DOI: http://dx.doi.org/10.1016/j.agee.2019.04.013

Publisher: Elsevier

All outputs in CentAUR are protected by Intellectual Property Rights law, including copyright law. Copyright and IPR is retained by the creators or other copyright holders. Terms and conditions for use of this material are defined in the End User Agreement. 


\section{CentAUR}

Central Archive at the University of Reading

Reading's research outputs online 
Evaluation and prediction of nitrogen use efficiency and outputs in faeces and urine in beef cattle

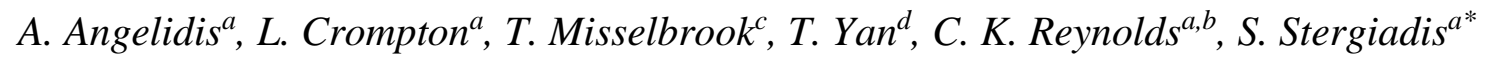

a Animal, Dairy and Food Chain Sciences Research Group, School of Agriculture, Policy and Development, University of Reading, PO Box 237, Earley Gate, Reading RG6 6AR, United Kingdom

${ }^{b}$ Centre for Dairy Research, University of Reading, School of Agriculture, Policy and Development, PO Box 237, Earley Gate, Reading RG6 6AR, United Kingdom

${ }^{\mathrm{c}}$ Rothamsted Research, North Wyke, Okehampton, Devon EX20 2SB, UK

${ }^{\mathrm{d}}$ Sustainable Agri-Food Sciences Division, Agriculture Branch, Agri-Food and Biosciences Institute, Large Park, Hillsborough, County Down, BT26 6DR, United Kingdom

* Corresponding author: s.stergiadis@ @reading.ac.uk Animal, Dairy and Food Chain Sciences

Research Group, School of Agriculture, Policy and Development, University of Reading, Earley Gate, PO Box 237, Reading, Berkshire, RG6 6AR, UK.

Keywords: nitrogen, efficiency, beef, urine, faeces, prediction, validation 


\section{Highlights}

- 289 intakes/outputs data were used to predict nitrogen $(\mathrm{N})$ output and efficiency

- Existing models underestimated $\mathrm{N}$ output from animals consuming $\mathrm{N}$-rich diets

- New models, including nutrient/energy contents and digestibility were more accurate

- More digestible diets with more metabolisable energy can improve $\mathrm{N}$ use efficiency

- Increasing dry matter digestibility by $100 \mathrm{~g} / \mathrm{kg}$ may reduce manure $\mathrm{N}$ output by 4.8

$\mathrm{g} / \mathrm{d}$ 


\section{ABSTRACT}

Beef cattle production is valuable to food security, contributing meat of high nutritional value. However, beef cattle are rather inefficient in utilising dietary nitrogen $(\mathrm{N})$, thus excreting substantial amounts of $\mathrm{N}$ in their urine and faeces and imposing an environmental burden. The aim of this study was to evaluate the main dietary factors affecting $\mathrm{N}$ use efficiency (NUE) in beef cattle and develop prediction models for $\mathrm{N}$ excretion in manure, faeces and urine. This knowledge is essential for the development and evaluation of cost-effective $\mathrm{N}$ mitigation strategies. A database of 289 treatment means was constructed from 69 published studies and 1194 animals. Data included diet contents of N, dry matter (DM), organic matter (OM), neutraldetergent fibre (NDF), acid-detergent fibre (ADF), ether extract, starch, ash, gross energy (GE), metabolisable energy (ME), and outputs of $\mathrm{N}$ in manure, in urine or in faeces. Regression equations to predict $\mathrm{N}$ outputs in manure (MNO), urine (UNO) and faeces (FNO), as well as various NUE indicators, were developed using residual maximum likelihood analysis. Evaluation of new and existing models was performed using the mean prediction error (MPE) to describe prediction accuracy. Manure, urine and faeces $\mathrm{N}$ outputs were predicted with improved accuracy (MPE from 0.557 to 0.162 ; from 0.764 to 0.208 ; and from 0.458 to 0.177 , respectively) when DM or OM digestibilities, and/or diet contents of N, NDF, ADF, Starch, OM, GE, ME, and/or forage proportion in the diet were added as predictors in different equations already containing either DM intake, $\mathrm{N}$ intake or body weight as primary predictor. New and existing models displayed an under-prediction of $\mathrm{N}$ outputs at the highest range of actual $\mathrm{N}$ outputs (when MNO > $207 \mathrm{~g} / \mathrm{d}, \mathrm{UNO}>109 \mathrm{~g} / \mathrm{d}$ ). However, some of the new equations had improved overall accuracy (best MPE for MNO, UNO and FNO being 0.162, 0.208 and 0.177 , respectively) and, when DM digestibility, and contents of N, NDF, Starch and ME were added as predictors in different equations, the extent of this under-prediction was also reduced (occurring when MNO > $208 \mathrm{~g} / \mathrm{d}$, UNO > $132 \mathrm{~g} / \mathrm{d}$ ). The regression models for NUE, 
demonstrated that diets which are more digestible and contain less $\mathrm{N}$ and fibre and more $\mathrm{ME}$, may reduce $\mathrm{N}$ excretions, but mitigation strategies will also need to account for the potential effect on animal productivity and health. 


\section{Introduction}

Ruminants play a critical role in global food security due to their unique capacity to transform fibrous feeds, low-quality protein and non-protein $\mathrm{N}$ sources into foods of high nutritional value. The main ruminant products (milk and meat) provide energy and useful nutrients to the human diet, such as proteins, rich in indispensable amino acids and bioactive peptides, fatty acids, minerals, vitamins and antioxidants (MacRae et al., 2005). However, livestock ruminants are relatively inefficient in utilising feed $\mathrm{N}$, and utilise approximately $20 \%$ of dietary $\mathrm{N}$ for growth (NRC, 2016), in part due to the rapid rumen degradation of feed protein that results in increased absorption of ammonia, which will then transform into urea in the liver and be excreted in the urine (Kennedy and Milligan, 1980). Another part of the urea which is synthesised in the liver would recycle back to the rumen either via saliva or absorption from the blood. This recycling mechanism is of high benefit to the animal because it provides the opportunity to survive and reproduce in a very wide range of ambient conditions, including cases where $\mathrm{N}$ intakes are very low, as well as the ability to synthesize protein from non-protein $\mathrm{N}$ (NRC, 2016). However, in farming conditions, where high growth rates are expected and beef are consuming high amounts of protein-rich feeds, this physiological mechanism contributes to their relatively low $\mathrm{N}$ use efficiency (NUE) (Tamminga, 1992). Although the main source $(50-80 \%)$ of absorbable protein in the small intestine originates from microbial synthesis (Storm and Ørskov, 2007), rumen microbes may be inefficient in converting degraded protein to microbial protein when the protein degradation is rapid (Nocek and Russell, 1988). Protein degradation in the rumen appears to be beneficial when animals are given low-quality feeds, but its negative impact on NUE can be significant in high-protein rations fed in intensively growing animals (Dewhurst et al., 2000). The proportion of N, which is excreted in the urine of beef cattle increases with increased dietary $\mathrm{N}$ and/or rumen degradable protein (Vasconcelos et al., 2009; Erickson and Klopfenstein, 2010; Koenig and 
Beauchemin, 2013a). Various experiments have identified an overall average NUE of around $25 \%$, with values ranging from $15 \%$ to $40 \%$ (Kohn et al., 2005; Huhtanen and Hristov, 2009; Calsamiglia et al., 2010), which means that approximately $75 \%$ of $\mathrm{N}$ intake is excreted in manure (the sum of faeces and urine).

Apart from the considerable financial loss due to the lower utilization of expensive feed protein, low NUE also poses an environmental burden (Hristov et al., 2011). ). N excretion in urine and faeces contributes to livestock greenhouse gas (GHG) emissions, through subsequent manure management and soil $\mathrm{N}$ losses as nitrous oxide $(\mathrm{N} 2 \mathrm{O})$, to air quality pollution and terrestrial and aquatic acidification and eutrophication through volatilization of ammonia (NH3) as well as aquatic eutrophication through nitrate (NO3) leaching (Tamminga, 2006). National and international agricultural and environmental agencies have repeatedly requested acting to reduce $\mathrm{N}$ inputs in soil, reducing either the application of inorganic $\mathrm{N}$ fertilisers and slurry, or the $\mathrm{N}$ excreted in faeces and urine of grazing animals (Tamminga, 2006). In addition, shifting $\mathrm{N}$ outputs from animal urine to faeces is beneficial from an environmental point of view, because urine mostly contains more labile $\mathrm{N}$, which can rapidly cycle through the environment as different forms of 'reactive $\mathrm{N}$ ' $\left(\mathrm{N}_{\mathrm{r}}\right)$ with damaging impacts (Galloway et al., 2003). Most of the $\mathrm{N}_{\mathrm{r}}$ in excreta originates from the hydrolytic action of the urease enzyme on excreted urinary urea, yielding ammonium as final product (Mobley et al., 1995; Varel et al., 1999). In faeces, in which $\mathrm{N}$ is mostly as organic $\mathrm{N}$ compounds, slower mineralization rates are observed (Muck and Steenhuis, 1982), leading to lower production rates of $\mathrm{N}_{\mathrm{r}}$.

Evaluation and understanding of the different factors affecting NUE, along with the development of models to predict $\mathrm{N}$ excretion in cattle urine and faeces is the cornerstone, not only for developing feeding management plans that minimize the waste of dietary N, but also to facilitate the calculation and reporting of $\mathrm{GHG}$ and $\mathrm{NH}_{3}$ emission estimates by the industry to the national and international agencies (European Commission, 2010; DEFRA, 2017). The 
fact that beef cattle generally excrete more $\mathrm{N}$ in urine $(40-70 \%$ of excreted $\mathrm{N})$ than in faeces (30-50\% of excreted N) when fed typical finishing diets (Hristov et al., 2011), advocates an additional need for the prediction of the partitioning of excreted N. The Department for Environment, Food and Rural Affairs (DEFRA) currently suggests a methodology for predicting $\mathrm{N}$ outputs in beef manure, mainly based on the gender, age and bodyweight of animals (DEFRA, 2013). This approach is convenient, as it does not require the measurement of complex predictors that are not readily available. However, many important parameters which profoundly influence NUE such as animal body weight, feed intake, diet chemical composition and digestibility parameters (Hoekstra et al., 2007; Stergiadis et al., 2015a) are not being simultaneously accounted for in the existing models, and a similar gap is observed in the published scientific literature over the last 15 years (Guo et al., 2004; Guo and Zoccarato, 2005; Yan et al., 2007; Hirooka, 2010; Waldrip et al., 2013; Dong et al., 2014; Reed et al., 2015). For example, Guo et al. (2004) and Guo and Zoccarato (2005) developed models for the prediction of total $\mathrm{N}$ output, based on data from Italian growing and finishing cattle, using $\mathrm{N}$ intake (NI) and $\mathrm{N}$ content in the empty body as predictors. Yan et al. (2007) presented equations predicting total $\mathrm{N}$ output in manure of beef cattle, incorporating different intakes, animal characteristics and diet chemical composition from digestibility studies in the UK. Hirooka (2010) introduced equations predicting $\mathrm{N}$ excretion in urine and faeces with dry matter intake (DMI) and NI as the only predictors, based on digestibility data from Japanese cattle. The study from Waldrip et al. (2013) was the first to present additional equations predicting the partitioning of excreted $\mathrm{N}$ in faeces and urine from cattle fed diets rich in concentrate feeds, using NI and N concentration of the diet as predictors. In addition, the existing models represent animals fed a rather specific range of diets within each study, thus individually representing specific production systems. A more recent study aimed to address this issue, and also predict the partitioning of excreted $\mathrm{N}$ in faeces and urine (Dong et al., 2014), using an extensive and 
diverse literature database, yet the models did not account for diet chemical composition beyond $\mathrm{N}$ content and $\mathrm{N}$ digestibility. Developing prediction models for $\mathrm{N}$ outputs in faeces and urine in beef cattle, that account for more dietary parameters, is urgent because diet chemical composition is known to affect NUE (Hoekstra et al., 2007) and provide significant predictors for $\mathrm{N}$ outputs in manure, faeces and urine, which improve prediction accuracy when added to equations already containing DMI and NI; this has been previously demonstrated in studies conducted in other production systems, such as lactating dairy cattle (Huhtanen et al., 2008; Kebreab et al., 2010; Reed et al., 2015), dairy cattle fed at maintenance energy levels (Stergiadis et al., 2015b) and heifers and non-lactating dairy cows (Reed et al. (2015).

Therefore, the aim of the present study was to (i) evaluate the effect of animal characteristics, feed intake, and diet energy contents, chemical composition and digestibility parameters, on NUE and (ii) develop prediction models for $\mathrm{N}$ outputs in manure, faeces and urine, using a wide range of combinations of predictors. For this, a literature database with studies of growing and finishing beef that represent several production systems, breeds, and dietary strategies, was used.

\section{Materials and methods}

\subsection{The database}

The database used in the present study was constructed from published studies that included $\mathrm{N}$ balance measurements and conducted with beef cattle from North and South America, Europe, Asia, Africa and Australia, between 1980 and 2017. An initial literature search was performed using Scopus database and the following keywords, alone or in several combinations: (i) N, (ii) output, excretion, or balance, (iii) beef, steer, calve, heifer, or bull, and (iv) faeces, urine or manure. This search identified 444 results. Results were retained in the database for the current study only when the animals were growing for meat production and at least the following parameters were presented: diet $\mathrm{N}$ content $(\mathrm{g} / \mathrm{kg}$ dry matter), DMI $(\mathrm{kg} / \mathrm{d})$ and outputs of $\mathrm{N}$ in 
manure $(\mathrm{MNO}, \mathrm{g} / \mathrm{d})$, in urine $(\mathrm{UNO}, \mathrm{g} / \mathrm{d})$ or in faeces $(\mathrm{FNO}, \mathrm{g} / \mathrm{d})$. When provided in the selected studies, the final database also included the following information: animal body weight (BW, kg), forage proportion in the diet (TF, \% of total dry matter), diet dry matter (DM) content (g/kg of fresh), diet organic matter (OM) content (g/kg DM), diet neutral-detergent fibre (NDF) content (g/kg DM), diet acid-detergent fibre (ADF) content (g/kg DM), diet ether extract (EE) content (g/kg DM), diet gross energy (GE) content (MJ/kg DM), diet digestible energy (DE) content (MJ/kg DM), diet metabolisable energy (ME) content (MJ/kg DM), diet ash content (g/kg DM), intakes of OM (OMI, kg/d), N (NI, g/d), NDF (NDFI, kg/d), ADF (ADFI, kg/d), EE (EEI, kg/d), GE (GEI, MJ/kg), DE (DEI, MJ/kg), ME (MEI, MJ/kg) and retained N (RN, g/d). Studies including hormonal, medical, antigen, and/or rumen infusion treatments were excluded. Where feasible, the following equations were used to calculate variables that were not presented in the literature studies, from other variables that were presented:

- $\quad$ Nutrient intake $(\mathrm{g} / \mathrm{d})=$ diet nutrient content $(\mathrm{g} / \mathrm{kg} \mathrm{DM}) \times \mathrm{DMI}(\mathrm{kg} / \mathrm{d})$

- $\quad \mathrm{MNO}(\mathrm{g} / \mathrm{d})=\mathrm{FNO}(\mathrm{g} / \mathrm{d})+\mathrm{UNO}(\mathrm{g} / \mathrm{d})$

- $\mathrm{RN}(\mathrm{g} / \mathrm{d})=\mathrm{NI}(\mathrm{g} / \mathrm{d})-\mathrm{FNO}(\mathrm{g} / \mathrm{d})-\mathrm{UNO}(\mathrm{g} / \mathrm{d})$

The resulting database included 69 studies, and 289 treatment means from 1,194 animals. The studies used to create the final database are listed in the Appendix. These, represented an as wide as possible range of animal and production characteristics, such as BW (65.5-600 kg), production stage (growing or finishing), breed (purebred or crossbred animals, mainly of Angus, Hereford, Charolais, Nellore and at a lesser extent Jersey, Piedmontese, Friesian, Red Poll and others), type of animal (heifers, steers, bulls,), production type (dairy-bred calves or beef herds), diet forage content $(0-100 \%$ of total DM) and diet ingredients. This aimed to ensure the development of prediction equations using diverse data describing a wide range of characteristics, which can be found across the spectra of published studies and beef production systems globally (e.g. from low-input to highly-intensive). Variation in individual variables, 
including mean, standard deviation, and minimum/maximum values, for all parameters used in the current study for the development of prediction equations, and related to animal and feed intake, composition and digestibility, are presented in Table 1.

The digestibility and $\mathrm{N}$ balance data in the individual studies used to create the database in the present study, were collected from digestibility experiments with animals restricted in individual digestibility crates or from feedlot operations with penned cattle. In 56 studies, total urine and/or faeces output was collected directly from the animals, whereas in 4 studies (Hankins et al., 2005; Buttrey et al., 2012; Sayer et al., 2013; Johnson et al., 2015), total manure scrapping of the feedlot pens was conducted. In 3 of the selected studies (Devant et al., 2000a; Seo et al., 2010; Cheng et al., 2017), total faeces and partial urine were collected, and animal's bodyweight and urine creatinine content have been used to calculate total urine output. In the two studies where, total urine and partial faeces were collected, faeces volume was calculated by using internal markers . In the study from Cole et al. (2003), faeces $\mathrm{N}$ excretion was estimated by measuring the internal marker acid-insoluble ash, after collection of partial faeces output, and $\mathrm{UNO}$ was calculated using the following equation: $\mathrm{UNO}=\mathrm{NI}-\mathrm{FNO}-\mathrm{RN}$. In the studies from Menezes et al. (2016), spot samples of faeces and urine were collected, and calculation of the total faeces production was performed by using the indigestible neutral detergent fibre as an internal marker. Kazemi-Bonchenari et al. (2016), used the same method for the collection of faeces and urine, measuring the apparent total tract digestibility of nutrients by using acid insoluble ash as internal marker. Finally, Krehbiel et al. (2000) only collected faeces grab samples for their analysis, and the results were used only for the development of FNO models in this study.

\subsection{Statistical analysis}

The data analyses were conducted using Genstat $17^{\text {th }}$ edition (VSN International, 2013). The regression equations were produced using residual maximum likelihood analysis (REML; 
(Robinson, 1987; Searle et al., 1992) in order for the potential random effects of individual study identifier, production stage, breed, type of animal, gender and production type to be accounted for. Linear regression relationships were produced, with the response variables being MNO (g/d), UNO (g/d), FNO (g/d) and the ratios of UNO/NI, RN/NI, UNO/MNO; and the explanatory variables being (i) DMI, NI, BW, N, N apparent digestibility (Nd) in single linear relationships (Tables 2 and 3; Figure 1 graphically presents the relationship between UNO/MNO and NI, Nd and dietary N), and (ii) DMI, NI, BW, TF, N, NDF, ADF, Starch, GE, ME, DMd, OMd, Nd in multiple linear regression models (Tables 2 and 3). The aim of the first approach was to produce simple models with readily available predictors, easy to use at commercial farms. The second approach aimed to produce models with improved prediction accuracy, by using more complex sets of predictors which account for animal and diet parameters influencing NUE and N outputs; these models can be used where availability of predictors is increased compared with commercial farms (e.g. at research environment). In addition, a set of equations mimicked the equations already presented in other studies, by using exactly the same predictors, in order to cross-validate new and existing equations of the same complexity against the same validation dataset.

The process for the development of prediction equations has been previously described (Stergiadis et al., 2015a; Stergiadis et al., 2015b; Stergiadis et al., 2016). In brief, the optimum random model developed for each response variable was built by fitting the same fixed effect model and the prospective models of the random variation, and decision whether to include a random factor in the model or not were made by using the changes in deviance. The significance of explanatory variables used in the multiple linear regressions was evaluated using the Wald statistic. In the current study, all predictors included in the equations showed a significant effect according to the Wald statistic. However, the predictors used in the equations that were developed with a sole aim to mimic the models found in other published work (Yan 
et al., 2007; Hirooka, 2010; Waldrip et al., 2013; Dong et al., 2014; Reed et al., 2015), so that they are all validated against the same validation dataset, were not in all circumstances significant according to the Wald statistic. The residual diagnostics of the final model were evaluated using normality plots. An approximate $\mathrm{R}^{2}$ (pseudo correlation coefficient; squared correlation of the response and the fitted values) was generated to represent the proportion of variability explained.

An internal validation, using previously described methods (Stergiadis et al., 2015a; Stergiadis et al., 2016) was performed to validate prediction equations developed in the current study. Equations previously published in literature were also externally validated against the same dataset. For this purpose, the whole database $(n=289)$ was divided into two sub-datasets of $n$ $=197$ (two-thirds of the data) and $n=92$ (one-third of the data). The first sub-dataset was used to produce prediction equations for MNO, UNO, FNO, UNO/NI, RN/NI and UNO/MNO by using exactly the same random and fixed factors (Appendix; Tables A1 and A2), as those developed using the whole database. An evaluation of these newly developed equations was performed, using the remaining one-third of the whole database, to assess their prediction accuracy (Tables 4 and 5). This evaluation was performed by the mean-square prediction error (MSPE) method using the following formula:

$$
\operatorname{MSPE}=\frac{1}{\mathrm{n}} \Sigma(\mathrm{P}-\mathrm{A})^{2}
$$

where $\mathrm{P}$ and $\mathrm{A}$ are the predicted and actual values respectively, and $\mathrm{n}$ represents the number of pairs of $\mathrm{P}$ and $\mathrm{A}$ values compared. Mean prediction error (MPE) was calculated to describe the prediction accuracy, using the following formula:

$$
\mathrm{MPE}=\sqrt{M S P E} /(\Sigma \mathrm{A} / \mathrm{n})
$$

The sub-dataset containing the one-third of the whole data was also used to evaluate 28 previously published equations (Appendix, Table A3) for the prediction of MNO, UNO, FNO 
and UNO/MNO, as presented by the different authors (Tables 4 and 5) (Yan et al., 2007; Hirooka, 2010; Waldrip et al., 2013; Dong et al., 2014; Reed et al., 2015). For the quantification of agreement between actual and predicted values, an analysis using Lin's Concordance Correlation Coefficient (Lin CCC) was conducted, and the outcome is presented in Table 4 (for MNO, UNO and FNO) and Table 5 (for UNO/NI, RN/NI and UNO/MNO). For the graphic representation of the agreement between predicted and actual values of MNO (Fig. 2), UNO (Fig. 3) and FNO (Fig. 4), Bland - Altman plots were used including (i) equations presented previously from other authors, (ii) equations developed in the current study using the same explanatory variables and (iii) equations developed in the current study with higher prediction accuracy than the existing ones, but with different explanatory variables. Lin CCC with $95 \%$ confidence interval are also presented in the same graphs.

\section{Results}

\subsection{Description of the collected data used in the prediction equations}

The mean, standard deviation, minimum and maximum measured values, coefficient of variation, number of observations for bodyweight, total forage proportion, diet chemical composition and energy contents, nutrient and energy intakes, diet digestibility parameters, $\mathrm{N}$ outputs and retention and $\mathrm{N}$ use efficiency parameters are shown in Table 1 . The variation observed, for the variables used to develop the prediction equations for $\mathrm{N}$ excretion was relatively high. For instance, there was a difference of $534.5 \mathrm{~kg}$ between the highest and the lowest bodyweight value in the database, with the forage proportion in the diets ranging between $0 \%$ and $100 \%$ of total DM. Maximum observed diet chemical components were between 1.1 times (for $\mathrm{OM}$ ) to 8.8 times (for DM) higher than minimum values, with maximum contents of N, NDF and ADF being also above 5 times higher, in comparison with the minimum contents. Maximum values of GE and ME contents of the diets were 1.3 and 2.1 times higher when compared with the lowest values, respectively. Highest DMI and NI values were more 
than 10 times higher than the respective lowest values, while maximum intakes of GE and ME were nearly 3 times higher than the lowest intakes. The difference observed between the highest and the lowest values of the diet digestibility for DM, OM and N, was 384.0, 408.5 and 618.0 $\mathrm{g} / \mathrm{kg}$, respectively. Highest values for $\mathrm{N}$ output were 7 and 47 times higher than the lowest ones for faeces and urine, respectively.

\subsection{Prediction of $N$ excretion in manure, urine and faeces}

When single and multiple linear prediction equations were developed for MNO, UNO and FNO using DMI, NI, and BW either as sole predictors or in combination with diet chemical composition, digestibility parameters and/or TF, the effect of DMI, N, NDF, ADF, GE, ME, NI, TF, OM, DMd, OMd, BW and Starch was significant according to the Wald statistic (Table 2; Eq. 1a-1k, Eq. 2a-2k, Eq. 3a-3q, respectively). Additional equations predicting MNO, UNO and FNO (Table 2; Eq. 11-1p, Eq. 2l-2n, Eq. 3r, respectively), were developed to include exactly the same predictors as in previously published equations for the same variables (Table A3; Eq. E1-E9,; Eq. E10-E17, Eq. E18-E23, respectively); in this case, the effect of the explanatory variables was not necessarily significant according to the Wald statistic (a list of the nonsignificant variables is provided in Table 2 and Table 3). MNO was positively correlated to DMI, NI, BW, N, GE, TF and ADF and negatively correlated to DMd and NDF. UNO was positively correlated to DMI, NI, BW, N, ADF and Starch and negatively correlated to ME. FNO was positively correlated to DMI, NI, BW, ADF, NDF and OM, and negatively correlated to ME, DMd and OMd. The MPEs observed in the newly developed equations ranged between 0.162 to $0.557 \mathrm{MNO}, 0.208$ to 0.741 for $\mathrm{UNO}$ and 0.177 to 0.409 for FNO, with the lower values, always representing an improved prediction accuracy.

When using the DMI and diet $\mathrm{N}$ content as predictors for MNO, UNO and FNO (Eq. 1b, 2b and 3b), the MPE was improved compared to using DMI as sole predictor (Eq. 1a, 2a and 3a), while adding GE to the latter models (Eq. 1c, 2d and 3e), further slightly reduced MPE. For 
the prediction of UNO and FNO, models including DMI, N, NDF and ADF were also produced (Eq. 2c, 3c and 3d), however their prediction accuracy was lower compared to the equations including GE as a predictor. For the prediction of FNO, the lowest MPE was observed in the model including DMI, N, GE and ME (Eq. 3f) as predictors, while replacing GE and ME with DMd further reduced the MPE (Eq. 3g).

A substantial reduction on MPE for the prediction of MNO, UNO and FNO was observed when NI was used as sole predictor instead of DMI (Eq. 1d, 2e and 3i). When TF was added as a secondary predictor in the above models for MNO and FNO, the MPE was slightly reduced (Eq. 1e and 3j), and a further reduction was seen when DMd was used instead of TF (Eq. 1g and 3n). Lower MPE than using NI as sole predictor for MNO, was observed when ADF was used as secondary predictor (Eq. 1f). The use of N, NDF and either DMd or OMd as secondary predictors in the model with NI as primary predictor, improved the prediction accuracy for UNO (Eq. 2f and $2 \mathrm{~g}$ ). The addition of OM to the model with NI and TF for the prediction of FNO (Eq. 3k), returned a lower MPE; but the lowest MPE was observed when N and NDF were included as secondary predictors to the model including NI as sole predictor (Eq. $3 \mathrm{~m}$ ).

Prediction accuracy was improved when $\mathrm{N}$ was used in combination with $\mathrm{BW}$ for the prediction of MNO, UNO and FNO (Eq.1i, 2i and 3q), instead of BW being used as sole predictor (Eq. $1 \mathrm{~h}, 2 \mathrm{~h}$ and $3 \mathrm{p})$. Furthermore, including both ADF and NDF to the former models for the prediction of MNO and UNO (Eq. $1 \mathrm{k}$ and $2 \mathrm{j}$ ), increased the prediction accuracy. The combination of BW as primary predictor and N, Starch and ME as secondary predictors (Eq. 2k), produced the model with the lowest MPE for the prediction of UNO.

\subsection{Prediction of NUE}

When single and multiple linear prediction equations were developed for UNO, expressed per NI (UNO/NI), RN expressed per NI (RN/NI) and UNO expressed per MNO (UNO/MNO) using DMI, NI, BW, N and Nd either as sole predictors or in combination with diet chemical 
composition, digestibility parameters and/or TF, the effect of DMI, N, Nd, TF, NI, DMd, NDF, ADF, OMd, BW was significant according to the Wald statistic (Table 3; Eq. 4a-4n, Eq. 5a5h, Eq. 6a-6m, respectively). UNO/NI was positively correlated to all included explanatory variables. RN/NI was positively correlated to $\mathrm{Nd}$ and negatively correlated to $\mathrm{DMI}, \mathrm{TF}, \mathrm{ADF}$, NDF, and BW. UNO/MNO was positively correlated to DMI, N, ADF, Nd, NI, OMd, BW and negatively correlated to NDF and TF.

The prediction accuracy when DMI was used as sole predictor for the prediction of UNO/NI and UNO/MNO (Eq. 4a and 6a), was slightly improved when $\mathrm{N}$ was also included as a secondary predictor (Eq. 4b and 6b). The substitution of $\mathrm{N}$ for $\mathrm{Nd}(\mathrm{Eq} .4 \mathrm{c})$ in the latter models improved the MPE (Eq. 4c and 6d), and further addition of TF in the model for UNO/NI resulted on the lowest MPE for this response variable (Eq. 4d). For the prediction of UNO/MNO, a model including DMI as primary predictor and N, NDF and ADF as secondary predictors (Eq. 6c), did not outperform than the model with DMI and Nd (Eq. 6d). DMI was used along with $\mathrm{TF}, \mathrm{Nd}, \mathrm{ADF}$ and $\mathrm{ADF}$ in various combinations for the prediction of $\mathrm{RN} / \mathrm{NI}$ (Eq. 5a-5e), with only marginal differences in the MPEs between equations of different complexity.

Prediction accuracy when using NI in combination with OMd for the prediction of UNO/NI and UNO/MNO (Eq. 4i and 6f) was slightly improved than that of using NI as sole predictor (Eq. 4e and 6e). Various models including NI as primary predictor and a combination of $\mathrm{N}$, DMd and NDF as secondary predictors for the prediction of UNO/NI (Eq. 4f-4h), had similar MPE but did not improve the model based on NI and OMd. For the prediction of RN/NI, NI was not identified as a significant predictor.

As a sole predictor, BW appeared to be significant only for the prediction of UNO/MNO (Eq. $6 \mathrm{~g}$ ), while the combination of $\mathrm{BW}$ and $\mathrm{N}$ was significant in the prediction of both UNO/NI and UNO/MNO (Eq. 4k and 6i). When BW was used along with $\mathrm{Nd}$ for the prediction of UNO/NI, 
RN/NI and UNO/MNO (Eq. 4l, 5g and 6k), all models showed improved MPE than all other models with BW as primary predictor, with the exception of RN/NI, where a combination of BW and TF improved MPE (Eq. 5f). The same predictors (BW and TF) used for the prediction of UNO/MNO (Eq. 6h) along with a model including BW, N, NDF and ADF (Eq. 6j) showed higher MPE compared to Eq. 6k.

The single linear models with $\mathrm{Nd}$ were produced for the prediction of all three response variables (Eq. 4n, 5h and 6m), but the observed MPE values were satisfactory only for the prediction of UNO/NI and UNO/MNO (Eq. $4 \mathrm{n}$ and $6 \mathrm{~m}$ ). Linear models with $\mathrm{N}$ developed for the prediction of UNO/NI and RN/NI (Eq. 4m and 61), showed also satisfactory MPE.

\subsection{Validation of prediction equations}

A total of 84 new equations, one for each equation developed in the current study by using the whole dataset, were developed from the two-thirds of the data by using exactly the same fixed and random model. The new equations are presented in the Appendix in (i) Table A1 for the prediction of MNO, UNO and FNO (Eq. A1-A16, B1-B14 and C1-C18, respectively), and (ii) Table A2 for the prediction of UNO/NI, RN/NI and UNO/MNO (Eq. D1-D14, F1-F8 and G1G13, respectively).

These newly developed equations as well as already published equations, presented in the Appendix (Table A3), for the prediction of MNO (Eq. E1-E9; Yan et al. (2007); Reed et al. (2015)), UNO (Eq. E10-E17; Hirooka (2010); Reed et al. (2015); Waldrip et al. (2013); Dong et al. (2014)), FNO (Eq. E18-E23; Hirooka (2010); Reed et al. (2015); Waldrip et al. (2013); Dong et al. (2014)) and UNO/MNO (Eq. E24-E28; Waldrip et al. (2013); Dong et al. (2014)), were validated against the remaining one-third of the data. Consequently, 28 external equations were validated, thus representing all equations in the aforementioned publications, except for a multilinear model including diet lignin content, a variable which was not available in our 
database. The results of this validation process are presented in Table 4 (for MNO, UNO and FNO) and Table 5 (for UNO/NI, RN/NI and UNO/MNO).

As regards to the equations produced in the present study, mean predicted values and actual values appeared to be very similar for most of the variables assessed. A difference less than 4 $\%, 4.5 \%, 0.2 \%, 1.8 \%, 14.4 \%$ and $2.16 \%$ was identified between mean predicted and actual values for MNO, UNO, FNO, UNO/NI, RN/NI and UNO/MNO, respectively, with mean differences for particular equations showing as low as $1.00 \%, 0.02 \%, 0.26 \%, 0.00 \%, 0.76 \%$ and $1.12 \%$ difference from the actual value, respectively. Equations' standard errors were less than $20 \%, 16 \%, 7 \%, 1 \%, 1 \%$ and $1 \%$ of the actual values for MNO, UNO, FNO, UNO/NI, RN/NI and UNO/MNO, respectively. The mean prediction errors of developed equations for each predicted variable averaged to $0.316(0.162-0.557)$ for MNO, $0.450(0.208-0.741)$ for UNO, $0.288(0.177-0.409)$ for FNO, $0.329(0.300-0.370)$ for UNO/NI, $0.465(0.456-0.490)$ for RN/NI and $0.228(0.148-0.287)$ for UNO/MNO.

Considering previously published equations, differences between predicted and actual values and standard errors were in most cases higher, while prediction accuracy was in most cases lower when compared with equations developed in the present study. For the prediction of MNO, predicted and actual values difference represented $0.42-8.44 \%$ of the actual values, standard errors represented 10.6-18.3\% of the actual values, while for all equations that were evaluated the average MPE was 0.308 , ranging between 0.202 and 0.552 . Among the external equations, the model proposed by Yan et al. (2007) (Eq. E3; including NI as sole predictor) showed the best prediction accuracy; while marginally lower prediction accuracy, was observed using the model proposed by Reed et al. (2015) (Eq. E1). For the prediction of UNO, predicted and actual values difference represented 1.64-20.6\% of the actual values, standard errors represented 19.1-30.6\% of the actual values and average MPE for the evaluated equations was 0.485 , ranging between 0.359 and 0.764 . The single linear model proposed by 
Waldrip et al. (2013) (Eq. E12; including NI as sole predictor) showed the lowest MPE for the prediction of UNO, with the single linear models using crude protein as sole predictor (Eq. E14 (Waldrip et al., 2013) and E15 (Dong et al., 2014)) showing the first and the second highest MPE, respectively. For the prediction of FNO, predicted and actual values difference represented 1.9-16.2 \% of the actual values, standard errors represented 8.7-30.3\% and the average MPE for all equations evaluated was 0.388 , ranging between 0.320 and 0.473 . The single linear model proposed by Dong et al. (2014) (Eq. E21; including NI as sole predictor) achieved the best prediction accuracy, being only slightly more accurate than the same model proposed by Waldrip et al. (2013) (Eq. E20). For the prediction of UNO/MNO, predicted and actual values difference represented $0.2-6.3 \%$ of the actual values, standard errors represented 7.4-16.4\% of the actual values, while for all equations evaluated, average MPE was 0.244, ranging between 0.175 and 0.265 . The single linear model proposed by Dong et al. (2014) (Eq. E28; including Nd as sole predictor) showed the lowest MPE, with all other proposed equations showing considerably lower prediction accuracy.

The Lin CCC was generated for all equations, including those developed in the present and previous studies (Yan et al. (2007); Hirooka (2010); Waldrip et al. (2013); Dong et al. (2014); Reed et al. (2015)) (Tables 4 and 5). Bland-Altman plots were developed to graphically describe part of the outcome of this analysis (Figures 2, 3 and 4). For the prediction of MNO (Fig. 2), new and previously published equations using the same predictors had similar Rc, tending to under-predict MNO when actual MNO was higher than $208(\mathrm{~g} / \mathrm{d})$ in the new equations and higher than $207(\mathrm{~g} / \mathrm{d})$ in the published equations, with the level of underprediction being the same in the new equations. Rc and scatter of the residual MNO across the zero line was improved when new models, including additional predictors (Eq. A7 and A14), were developed in the present study. For the prediction of UNO (Fig. 3), new and previously published equations using the same predictors had similar Rc and in this case, the under- 
prediction of UNO was apparent when actual UNO was higher than $132(\mathrm{~g} / \mathrm{d})$ in the new equations and higher than 109 (g/d) in the published equations, with the level of underprediction only marginally being improved in the new equations. Rc and scatter of the residual MNO across the zero line was improved when new models, including additional predictors (Eq. B6 and B11), were developed in the present study. For the prediction of FNO (Fig. 4), new and previously published equations using the same predictors had different Rc in the case of equations $\mathrm{C} 9$ and $\mathrm{E} 21$, and the same for equations $\mathrm{C} 1$ and $\mathrm{E} 18 . \mathrm{Rc}$ and scatter of the residual MNO across the zero line was improved when new models, including additional predictors (Eq. C7 and C13) were developed in the present study.

\section{Discussion}

\subsection{Assessing predictors for $N$ excretion in manure, urine and faeces}

The positive correlation of TF with MNO has been previously reported (Yan et al., 2007). The positive correlation of TF with FNO and UN/NI, and the negative correlation with RN/NI maybe because increased proportion of forage in a diet reduces microbial protein flow in the small intestine (Clark et al., 1992). High-forage diets may be deficient in non-structural carbohydrates (e.g. starch and sugars), which are rapidly available energy sources for rumen microbes, thus reducing microbial growth (NRC, 2016). Other studies further reported that cows with high intakes of grazed grass (Hoekstra et al., 2007) or grass silage (Weiss et al., 2003), which are rich in rapidly degradable protein and non-protein N, utilised more slowly fermented structural carbohydrates and amino acids (rather than e.g. starch) to cover their energy needs, thereby reducing rumen microbial capacity in capturing the fast released amino acids; this eventually increased NH3 and urea synthesis and UNO (Tas et al., 2006; Hoekstra et al., 2007) and MNO (Weiss et al., 2003). These results support that adequate supply of fermentable energy to rumen microbes is essential in order to improve NUE and reduce $\mathrm{N}$ outputs (Tas et al., 2006), as a mitigation strategy in ruminants at high forage intakes. 
Furthermore, the slow rumen passage rate of feed in forage-rich diets, due to high fibre content, may favour microbial recycling in the rumen (via protozoal predation and death), thus increasing the proportion of energy deflected for maintenance and reducing microbial growth rates (Sniffen and Robinson, 1987). Fibre-rich forage-based diets has also been shown to directly increase the total faecal OM output, by increasing feed intake and lowering diet digestibility (Hales et al., 2014); this may explain the negative correlation of TF with UNO/MNO because the increased UNO, is coupled by a simultaneous increase in FNO. As a result, the increased aggregated denominator (UNO plus FNO) is constantly higher than the increase in UNO alone thus leading to a constantly lower UNO/MNO ratio.

The positive correlation of NI with MNO, UNO and FNO is in line with previous studies (Yan et al., 2007; Waldrip et al., 2013; Dong et al., 2014). Based on the findings of the present study, an $1 \mathrm{~g}$ increase in daily supply of $\mathrm{N}$ in beef diets, would increase outputs of $\mathrm{N}$ in manure, urine and faeces by $0.761 \mathrm{~g}, 0.597 \mathrm{~g}$ and $0.158 \mathrm{~g}$, respectively. Increased NI has been reported as the main driver for increased $\mathrm{N}$ excretion, especially in urine, of beef cattle (Devant et al., 2000b; Hoffman et al., 2001). Conversely, increasing NI in beef cattle has only a marginal effect on FNO (Koenig et al., 2004; Vasconcelos et al., 2009). The higher effect of NI on UNO than FNO is because the physiological pathway to remove excess blood urea in ruminants is via urine (Kebreab et al., 2001; Higgs et al., 2012). The positive correlation between NI and UNO/NI and UNO/MNO, has been previously shown (Waldrip et al., 2013; Dong et al., 2014). This is in line with several other studies showing that any reduction in NI not only reduces UNO and MNO, but also the UNO/MNO ratio (Kröber et al., 2000; Castillo et al., 2001; Kebreab et al., 2001) and this is because the reduction in UNO is greater than the relative reduction in FNO, and subsequently MNO, when NI is reduced. Switching toward more N excreted in faeces, rather than urine, is preferable from an environmental point of view, as it may result in lower $\mathrm{N}_{2} \mathrm{O}, \mathrm{NH}_{3}$ and $\mathrm{NO}_{3}$ emissions (Kebreab et al., 2001; van der Weerden et 
al., 2011). In dairy cattle, Kebreab et al. (2001) reported that diets with of over $147 \mathrm{~g}$ protein per $\mathrm{kg} \mathrm{DM}$ in dairy cattle would drive the excretion of $\mathrm{N}$ mostly towards urine; the current study demonstrated similar findings for beef cattle. However, reduction in protein supply should be done cautiously, so that rumen function and/or productivity are not compromised (Yan et al., 2006). The positive correlation of DMI and BW with UNO, FNO, MNO, UNO/NI and UNO/MNO may be explained by their positive correlation to NI. Heavier animals have higher DMI, and eventually N, but also typically represent animals in their finishing period, being fed N-rich finishing diets (Menezes et al., 2016).

ME was negatively correlated to $\mathrm{N}$ outputs, because efficiency of microbial $\mathrm{CP}$ synthesis, largely relies upon the energy supply to rumen microbes for growth and maintenance (Stouthamer, 1973; Hespell and Bryant, 1979). When energy supply is adequate, amino acids will be used towards microbial protein synthesis; otherwise they will be deaminated, yielding a carbon skeleton to be transformed into VFA (Bach et al., 2005). Therefore, efficient microbial protein synthesis in the rumen and NUE require adequate dietary supply of energy-yielding compounds (Tas et al., 2006). Previously published equations confirmed the negative correlation of both MEI and dietary ME with MNO in beef cattle (Yan et al., 2007; Reed et al., 2015). The contrasting correlation of FNO with ME (negative) and GE (positive), may be attributed to the confounding/balancing effects between these different predictors, rather than explaining a metabolic pathway.

Digestibility parameters (DMd, OMd, Nd) were positively correlated to UNO, UNO/NI, RN/NI, UNO/MNO and negatively correlated to MNO and FNO. The positive correlation of digestibility parameters with UNO may be explained by the fact that highly digestible diets are potentially rich in protein and lower in ADF, thus increasing NI and eventually UNO (Broderick, 2007). On the other hand, when diets are low in protein, there will be a lack of available $\mathrm{N}$ to rumen microbes for growth and maintenance, leading to reduced overall feed 
fermentation, and subsequently apparent digestibility (Guliński et al., 2016); an effect that may be reversed when cattle on fibre-rich poor quality forages are supplemented with soybean meal in the study from Mathis et al. (1999). Regarding OMd, NRC (2016) reported that an effective microbial protein synthesis in the rumen requires high rates of fermentation of OM but also a simultaneous high availability of $\mathrm{N}$. The negative correlation of digestibility parameters to MNO and FNO may be explained by the fact that low digestibility diets increase faecal output (by definition (NRC, 2016)) and consequently nutrient excretion in faeces (including N). According to the present study, a $100 \mathrm{~g} / \mathrm{kg}$ increase in DMd could reduce FNO up to $8 \mathrm{~g} / \mathrm{d}$. In addition, highly-digestible diets provide higher amounts of energy to rumen microbes, thus increasing microbial protein flow in the gut and amino acid absorption and reducing MNO and FNO (Broderick, 2007).

The positive correlation of structural carbohydrates (NDF, ADF) with MNO, UNO, FNO, and $\mathrm{UN} / \mathrm{NI}$ is consistent with the previously discussed correlation of TF, as NDF can be between 30 and $75 \%$ of forage DM, which is typically higher than NDF content in concentrate feeds (NRC, 2016). The present study indicated that an increase of $100 \mathrm{~g} / \mathrm{kg} \mathrm{DM}$ in NDF or ADF, would increase outputs MNO, UNO and FNO up to 9.9, 4.2 and $3 \mathrm{~g} / \mathrm{d}$ respectively. Structural carbohydrates provide lower levels of energy, than starch, for microbial protein synthesis (Bach et al., 2005), and therefore reduce ammonia capture into microbial protein and leaves higher amounts of unutilised NH3 in the rumen (Belanche et al., 2012; Zhang et al., 2015). In dairy cows, Belanche et al. (2012) found that high-fibre diets resulted in 2.3 times higher rumen NH3 concentrations than cows consuming high-starch diets, potentially due to the higher $\mathrm{N}$ capture by rumen bacteria when diet contained more fermentable carbohydrates. In addition, increasing dietary NDF reduces $\mathrm{Nd}$ as carbohydrates with a slower fermentation rate may reach the hindgut, providing energy for hindgut microbes that capture $\mathrm{N}$, and are subsequently excreted through faeces, thus increasing FNO (Higgs et al., 2012). The appearance in some instances 
(MNO, UNO, UNO/MNO) of both positively and negatively correlated fibre fractions, can be attributed to (i) confounding/balancing effects with other predictors in the same model and/or (ii) the lack of water-soluble carbohydrate intake data, which would account for the rumen protein/energy equilibrium in the model; information which is particularly relevant in highforage diets (Stergiadis et al., 2015b).

Higher supply of fermentable $\mathrm{OM}$ in the rumen, increase the production of microbial protein synthesis (Hoover and Stokes, 1991), and shifts $\mathrm{N}$ excretion from urine to faeces; this may explain the positive correlation between dietary OM and FNO. In a previous study, estimates of microbial CP synthesis display significant variability, ranging from $12-54 \mathrm{~g} \mathrm{~N} / \mathrm{kg}$ of truly fermented $\mathrm{OM}$ in the rumen, while the desirable value of $29 \mathrm{~g}$ of bacterial $\mathrm{N} / \mathrm{kg}$ of fermented OM, is rarely observed in beef cattle (Bach et al., 2005).

\subsection{Equation validation}

The combination of NI and DMd produced the most accurate model for the prediction of MNO and may be recommended when these predictors are available, e.g. research operations. In contrast to Yan et al. (2007), the prediction accuracy was improved by up to $20 \%$ when adding either TF, ADF or DMd in equations already containing only NI, although model complexity is also increased; Yan et al. (2007) have shown that adding BW or TF did not improve prediction accuracy. Equations based on TF and ADF, may be relevant to commercial farms because these variables are routinely available, in contrast to digestibility parameters. DMI alone does not account for dietary $\mathrm{N}$ and therefore it did not satisfactorily predicted MNO. However, when diet $\mathrm{N}$ content and GE or MEI are also added, the models have similar accuracy to those using DMd and NI. This is beneficial because feed GE and feed predicted ME are routinely available on commercial farms, in contrast with DMd. Other authors (Yan et al., 2007; Reed et al., 2015), have also demonstrated the importance of including energy variables (ME) in prediction equations for MNO. Feed intake parameters are commonly unavailable in 
commercial farms. Thus, more readily available predictors, such as BW and diet $\mathrm{N}$ content may be used to improve prediction of MNO (Yan et al., 2007). The current study demonstrated that including NDF and ADF, also commonly assessed in feed analysis, may further improve the accuracy of MNO prediction when BW and diet $\mathrm{N}$ are already used. The under-prediction of MNO, when actual MNO > $207 \mathrm{~g} / \mathrm{d}$, was observed in all new and previously published equations. This may be expected because although NI is a good predictor for MNO, there is still a limit on the amount of variation that can be explained when used as a sole predictor. In this $\mathrm{MNO}$ range, adding $\mathrm{BW}$ and TF as predictors in equations already containing NI, as previously done in other work (Yan et al., 2007; Reed et al., 2015), did not markedly improve model accuracy. However, equations using DMd or ME intake (in addition to NI or DMI plus diet $\mathrm{N}$ content) substantially reduced the extent of this under-prediction, potentially because energy and digestibility parameters may explain more variation by being highly influential to NUE (Bach et al., 2005).

Interestingly, UNO was most accurately predicted when DMI, N, and GE were used as predictors and this may be recommended as optimum model for use in growing or finishing beef. The fact there is no requirement for digestibility parameters is beneficial because these are only measurable in research environment. The low prediction accuracy when DMI and BW were used as sole predictors is consistent with Dong et al. (2014), and mostly attributed to lack of any dietary $\mathrm{N}$ information in the models. The high MPE when feed intake parameters were not used, and models relied solely on BW, makes it very challenging to predict UNO in commercial farms, where feed intake is not commonly available. This may be explained by the strong positive correlation between NI and UNO (Archibeque et al., 2001; Brake et al., 2010), which can improve prediction accuracy when NI is included in the models as predictor (Waldrip et al., 2013; Dong et al., 2014; Reed et al., 2015). In the present study, using NI as sole predictor showed an under-prediction of UNO, when actual UNO $>109 \mathrm{~g} / \mathrm{d}$, but when CP 
and BW were additionally used the under-prediction was extended to UNO > $94 \mathrm{~g} / \mathrm{d}$. The present study demonstrated that under-prediction of UNO, at high actual UNO levels, can only be reduced when digestibility or energy parameters are added to models containing feed intake parameters. A possible explanation for this is that the current, and most of the published models (Waldrip et al., 2013; Dong et al., 2014; Reed et al., 2015), have relied on data which represent UNO lower than the range that the under-prediction is observed. Given that the main excretion mechanism of excess NI is urine (Varel et al., 1999), a proportionately higher amount of NI would be released in the urine of animals consuming/excreting high, rather than low, amounts of $\mathrm{N}$; something that the previously published models could not accurately account for.

The most accurate prediction of FNO was achieved by a model including DMI, N, GE and ME thus further demonstrating the importance to include energy parameters in the prediction of $\mathrm{N}$ outputs in beef. The significance of DMI as a predictor for FNO has been shown previously in non-lactating non-pregnant dairy cattle by Stergiadis et al. (2015b). NI alone was reliable predictor for FNO, as previously shown in beef cattle (Vasconcelos et al., 2009; Waldrip et al., 2013; Dong et al., 2014). BW alone showed a relatively low prediction accuracy, even when diet $\mathrm{N}$ content was added in the model. Reed et al. (2015) suggested that BW has a stronger correlation with UNO than FNO. These results further highlight the challenge in accurately predicting $\mathrm{N}$ outputs from beef when feed intake is not known. When NI was used as sole predictor, the equation from Waldrip et al. (2013) performed slightly better (visually) than the new equation in the Bland-Altman plots, but had higher MPE; although both equations had relatively high MPE. When using DMI as sole predictor, the model from Hirooka (2010) had a less desirable scatter of data across the zero line in the Bland-Altman plots, than the new model. The issue of under-prediction of MNO and UNO outputs at their higher actual levels, was not seen for FNO, potentially because the effect of NI on FNO is less than on UNO; once the metabolizable protein and the ruminally degradable protein requirements are met, the 
increased $\mathrm{N}$ excretion is diverted mostly in the urine (Vasconcelos et al., 2009; Koenig and Beauchemin, 2013a, b). The validation process and the Bland-Altman plots in the present study also demonstrated that in order to generate models with an improved scatter of data and prediction accuracy the inclusion of parameters such as NDF, diet energy contents and digestibility are necessary.

Equations for the prediction of UN/NI and RN/NI have not been previously presented for beef cattle; these were developed in this study as indicators of NUE and their prediction accuracy was overall low. This might be expected because $\mathrm{RN}$ reported in $\mathrm{N}$ balance studies are potentially higher than the actual values, due to $\mathrm{NH}_{3}$ losses from faeces and urine on collection as well as unaccounted $\mathrm{N}$ for hair or scurf losses (Reynolds and Kristensen, 2008). The best single linear model for the prediction of $\mathrm{UNO} / \mathrm{MNO}$, was the one using $\mathrm{Nd}$, as previously shown (Dong et al., 2014). Adding DMI or BW to this model only marginally improved the prediction accuracy, thus indicating that $\mathrm{Nd}$ alone can sufficiently describe the $\mathrm{N}$ partitioning in faeces and urine. $\mathrm{Nd}$ directly influences the production of $\mathrm{NH}_{3}$ in the rumen and the passage of microbial protein to the small intestine; with increased $\mathrm{NI}$ and $\mathrm{Nd}$, a greater amount of $\mathrm{N}$ is absorbed as $\mathrm{NH}_{3}$ from the rumen and the excess $\mathrm{N}$ would be excreted in urine (Dong et al., 2014). Waldrip et al. (2013) developed prediction equations for UNO/MNO in beef cattle, using NI or CP as sole predictors, but their models showed low prediction accuracy in the present study.

\section{Conclusion}

The proposed study demonstrated that using models that include diet chemical composition, digestibility and metabolisable energy content parameters, in addition to feed and nitrogen intake, as predictors, can improve the prediction accuracy of existing models for nitrogen outputs in manure, faeces and urine in beef cattle. Existing equations have been found to underpredict nitrogen outputs in manure, faeces and urine in animals excreting high amounts of 
nitrogen and the new (although more complex) equations can be used to minimise this inaccuracy, where the additional predictors are available. In order to reduce nitrogen outputs and improve nitrogen use efficiency, which will subsequently reduce the potential for ammonia and nitrous oxide emissions and nitrate leaching from beef production systems, feeding a diet which is more digestible, contains less nitrogen (although care is needed in order to maintain growth rates) and fibre, and has a higher metabolisable energy concentration, is essential. 


\section{References}

Archibeque, S.L., Burns, J.C., Huntington, G.B., 2001. Urea flux in beef steers: effects of forage species and nitrogen fertilization. J. Anim. Sci. 79, 1937-1943.

Bach, A., Calsamiglia, S., Stern, M.D., 2005. Nitrogen metabolism in the rumen. J. Dairy Sci. 88, E9-E21.

Belanche, A., Doreau, M., Edwards, J.E., Moorby, J.M., Pinloche, E., Newbold, C.J., 2012. Shifts in the rumen microbiota due to the type of carbohydrate and level of protein ingested by dairy cattle are associated with changes in rumen fermentation. J. Nutr. 142, 1684-1692.

Brake, D.W., Titgemeyer, E.C., Jones, M.L., Anderson, D.E., 2010. Effect of nitrogen supplementation on urea kinetics and microbial use of recycled urea in steers consuming corn-based diets. J. Anim. Sci. 88, 2729-2740.

Broderick, G.A., 2007. Reduced crude protein rations for high producing cows: Production and environmental effects. 69th Cornell Nutrition Conference for Feed Manufacturers, New York.

Buttrey, E.K., Cole, N.A., Jenkins, K.H., Meyer, B.E., McCollum, I.F.T., Preece, S.L.M., Auvermann, B.W., Heflin, K.R., MacDonald, J.C., 2012. Effects of twenty percent corn wet distillers grains plus solubles in steam-flaked and dry-rolled corn-based finishing diets on heifer performance, carcass characteristics, and manure characteristics. J. Anim. Sci. 90, 5086-5098.

Calsamiglia, S., Ferret, A., Reynolds, C.K., Kristensen, N.B., van Vuuren, A.M., 2010. Strategies for optimizing nitrogen use by ruminants. Animal 4, 1184-1196. 
Castillo, A.R., Kebreab, E., Beever, D.E., Barbi, J.H., Sutton, J.D., Kirby, H.C., France, J., 2001. The effect of protein supplementation on nitrogen utilization in lactating dairy cows fed grass silage diets. J. Anim. Sci. 79, 247-253.

Cheng, L., Judson, H.G., Bryant, R., Mowat, H., Guinot, L., Hague, H., Taylor, S., Edwards, G.R., 2017. The effects of feeding cut plantain and perennial ryegrass-white clover pasture on dairy heifer feed and water intake, apparent nutrient digestibility and nitrogen excretion in urine.

Clark, J.H., Klusmeyer, T.H., Cameron, M.R., 1992. Microbial protein synthesis and flows of nitrogen fractions to the duodenum of dairy cows. J. Dairy Sci. 75, 2304-2323.

Cole, N.A., Greene, L.W., McCollum, F.T., Montgomery, T., McBride, K., 2003. Influence of oscillating dietary crude protein concentration on performance, acid-base balance, and nitrogen excretion of steers. J. Anim. Sci. 81, 2660-2668.

DEFRA, 2013. NVZ Guidance - Blank 'farmer completion' and 'standard values' tables. https://www.gov.uk/government/uploads/system/uploads/attachment_data/file/408227 /nvz-guidance-blank-completion-data-tables-201312.xlsm (accessed 24 August 2018).

DEFRA, 2017. Agricultural statistics and climate change (8th edition) - full report. https://www.gov.uk/government/statistics/agricultural-statistics-and-climate-change (accessed 23 August 2018).

Devant, M., Ferret, A., Gasa, J., Calsamiglia, S., Casals, R., 2000a. Effects of protein concentration and degradability on performance, ruminal fermentation, and nitrogen metabolism in rapidly growing heifers fed high-concentrate diets from 100 to $230 \mathrm{~kg}$ body weight.

Devant, M., Ferret, A., Gasa, J., Calsamiglia, S., Casals, R., 2000b. Effects of protein concentration and degradability on performance, ruminal fermentation, and nitrogen 
metabolism in rapidly growing heifers fed high-concentrate diets from 100 to $230 \mathrm{~kg}$ body weight 1 . Journal of animal science $78,1667-1676$.

Dewhurst, R.J., Davies, D.R., Merry, R.J., 2000. Microbial protein supply from the rumen. Anim. Feed Sci. Technol. 85, 1-21.

Dong, R.L., Zhao, G.Y., Chai, L.L., Beauchemin, K.A., 2014. Prediction of urinary and fecal nitrogen excretion by beef cattle. J. Anim. Sci. 92, 4669-4681.

Erickson, G., Klopfenstein, T., 2010. Nutritional and management methods to decrease nitrogen losses from beef feedlots1. Journal of animal science 88, E172-E180.

European Commission, 2010. The EU nitrates directive. http://ec.europa.eu/environment/pubs/pdf/factsheets/nitrates.pdf (accessed 23 August 2018).

Galloway, J.N., Aber, J.D., Erisman, J.W., Seitzinger, S.P., Howarth, R.W., Cowling, E.B., Cosby, B.J., 2003. The nitrogen cascade. BioSci. 53, 341-356.

Guliński, P., Salamończyk, E., Krzysztof, M., 2016. Improving nitrogen use efficiency of dairy cows in relation to urea in milk - a review. Anim. Sci. Pap. Rep. 34, 5-23.

Guo, K., Mimosi, A., Fortina, R., Zoccarato, I., 2004. A computer model to predict the nitrogen excretion in growing-finishing cattle. Livest. Prod. Sci. 88, 273-284.

Guo, K., Zoccarato, I., 2005. A dynamic model to predict the nitrogen excretion in growingfinishing cattle. Ecol. Modell. 187, 219-231.

Hales, K.E., Brown-Brandl, T.M., Freetly, H.C., 2014. Effects of decreased dietary roughage concentration on energy metabolism and nutrient balance in finishing beef cattle. J. Anim. Sci. 92, 264-271.

Hankins, S.L., Arseneau, J.D., Lemenager, R.P., Sutton, A.L., 2005. Performance, Carcass Traits, and Nutrient Excretion of Beef Feedlot Cattle Fed a Corn Gluten Feed 
Diet11Journal paper no. 17288 of the Purdue University Agricultural Research Programs. The Professional Animal Scientist 21, 1-6.

Hespell, R.B., Bryant, M.P., 1979. Efficiency of rumen microbial growth: influence of some theoretical and experimental factors on YATP. J. Anim. Sci. 49, 1640-1659.

Higgs, R.J., Chase, L.E., Van Amburgh, M.E., 2012. Development and evaluation of equations in the Cornell Net Carbohydrate and Protein System to predict nitrogen excretion in lactating dairy cows. J. Dairy Sci. 95, 2004-2014.

Hirooka, H., 2010. Systems approaches to beef cattle production systems using modeling and simulation. J. Anim. Sci. 81, 411-424.

Hoekstra, N.J., Schulte, R.P.O., Struik, P.C., Lantinga, E.A., 2007. Pathways to improving the $\mathrm{N}$ efficiency of grazing bovines. Eur. J. Agron. 26, 363-374.

Hoffman, P.C., Esser, N.M., Bauman, L.M., Denzine, S.L., Engstrom, M., Chester-Jones, H., 2001. Short communication: effect of dietary protein on growth and nitrogen balance of Holstein heifers. J. Dairy Sci. 84, 843-847.

Hoover, W.H., Stokes, S.R., 1991. Balancing carbohydrates and proteins for optimum rumen microbial yield. J. Dairy Sci. 74, 3630-3644.

Hristov, A.N., Hanigan, M., Cole, A., Todd, R., McAllister, T.A., Ndegwa, P.M., Rotz, A., 2011. Review: Ammonia emissions from dairy farms and beef feedlots. Can. J. Anim. Sci. 91, 1-35.

Huhtanen, P., Hristov, A.N., 2009. A meta-analysis of the effects of dietary protein concentration and degradability on milk protein yield and milk $\mathrm{N}$ efficiency in dairy cows. J. Dairy Sci. 92, 3222-3232.

Huhtanen, P., Nousiainen, J.I., Rinne, M., Kytölä, K., Khalili, H., 2008. Utilization and partition of dietary nitrogen in dairy cows fed grass silage-based diets. J. Dairy Sci. 91, 3589-3599. 
Johnson, J.M., Shreck, A.L., Nuttelman, B.L., Burken, D.B., Erickson, G.E., Rincker, M.J., Cecava, M.J., Klopfenstein, T.J., 2015. Effects of twenty percent alkaline-treated corn stover without or with yucca extract on performance and nutrient mass balance of finishing steers fed modified distillers grains-based diets. J. Anim. Sci. 93, 3034-3043.

Kazemi-Bonchenari, M., Salem, A.Z.M., Ghasemi, E., 2016. Effect of urea supplementation in diet based on barley grain or corn silage on performance, digestion, rumen fermentation and microbial protein synthesis in Holstein bull calves. Indian J. Anim. Sci. 86, 313317.

Kebreab, E., France, J., Beever, D.E., Castillo, A.R., 2001. Nitrogen pollution by dairy cows and its mitigation by dietary manipulation. Nutr. Cycl. Agroecosys. 60, 275-285.

Kebreab, E., Strathe, A.B., Dijkstra, J., Mills, J.A.N., Reynolds, C.K., Crompton, L.A., Yan, T., France, J., 2010. Energy and protein interactions and their effect on nitrogen excretion in dairy cows. 3rd EAAP International Symposium on Energy and Protein Metabolism and Nutrition, pp. 417-426.

Kennedy, P.M., Milligan, L.P., 1980. The degradation and utilization of endogenous urea in the gastrointestinal tract of ruminants: a review. Can. J. Anim. Sci. 60, 205-221.

Koenig, K.M., Beauchemin, K.A., 2013a. Nitrogen metabolism and route of excretion in beef feedlot cattle fed barley-based backgrounding diets varying in protein concentration and rumen degradability. J. Anim. Sci. 91, 2295-2309.

Koenig, K.M., Beauchemin, K.A., 2013b. Nitrogen metabolism and route of excretion in beef feedlot cattle fed barley-based finishing diets varying in protein concentration and rumen degradability. J. Anim. Sci. 91, 2310-2320.

Koenig, K.M., Beauchemin, K.A., Rode, L.M., 2004. Effect of protein source on microbial protein synthesis and nutrient digestion in beef cattle fed barley grain-based diets. Can. J. Anim. Sci. 84, 481-490. 
Kohn, R.A., Dinneen, M.M., Russek-Cohen, E., 2005. Using blood urea nitrogen to predict nitrogen excretion and efficiency of nitrogen utilization in cattle, sheep, goats, horses, pigs, and rats. J. Anim. Sci. 83, 879-889.

Krehbiel, C.R., Kreikemeier, K.K., Ferrell, C.L., 2000. Influence of Bos indicus crossbreeding and cattle age on apparent utilization of a high-grain diet. J. Anim. Sci. 78, 1641-1647.

Kröber, T.F., Külling, D.R., Menzi, H., Sutter, F., Kreuzer, M., 2000. Quantitative effects of feed protein reduction and methionine on nitrogen use by cows and nitrogen emission from slurry. J. Dairy Sci. 83, 2941-2951.

MacRae, J., O'Reilly, L., Morgan, P., 2005. Desirable characteristics of animal products from a human health perspective. Livest. Prod. Sci. 94, 95-103.

Mathis, C.P., Cochran, R.C., Stokka, G.L., Heldt, J.S., Woods, B.C., Olson, K.C., 1999. Impacts of increasing amounts of supplemental soybean meal on intake and digestion by beef steers and performance by beef cows consuming low-quality tallgrass-prairie forage. J. Anim. Sci. 77, 3156-3162.

Menezes, A.C.B., Valadares Filho, S.C., Costa e Silva, L.F., Pacheco, M.V.C., Pereira, J.M.V., Rotta, P.P., Zanetti, D., Detmann, E., Silva, F.A.S., Godoi, L.A., Rennó, L.N., 2016. Does a reduction in dietary crude protein content affect performance, nutrient requirements, nitrogen losses, and methane emissions in finishing Nellore bulls? Agric. Ecosyst. Environ. 223, 239-249.

Mobley, H.L., Island, M.D., Hausinger, R.P., 1995. Molecular biology of microbial ureases. Microbiol. Rev. 59, 451-480.

Muck, R.E., Steenhuis, T.S., 1982. Nitrogen losses from manure storages. Agric. Wastes 4, 4154. 
Nocek, J.E., Russell, J.B., 1988. Protein and energy as an integrated system. Relationship of ruminal protein and carbohydrate availability to microbial synthesis and milk production. J. Dairy Sci. 71, 2070-2107.

NRC, 2016. Nutrient Requirements of Beef Cattle: Eighth Revised Edition. The National Academies Press, Washington, DC.

Reed, K.F., Moraes, L.E., Casper, D.P., Kebreab, E., 2015. Predicting nitrogen excretion from cattle. J. Dairy Sci. 98, 3025-3035.

Reynolds, C.K., Kristensen, N.B., 2008. Nitrogen recycling through the gut and the nitrogen economy of ruminants: An asynchronous symbiosis. J. Anim. Sci. 86, E293-E305.

Robinson, D.L., 1987. Estimation and use of variance components. J. R. Stat. Soc. Series D The Statistician 36, 3-14.

Sayer, K.M., Buckner, C.D., Erickson, G.E., Klopfenstein, T.J., Macken, C.N., Loy, T.W., 2013. Effect of corn bran and steep inclusion in finishing diets on diet digestibility, cattle performance, and nutrient mass balance. J. Anim. Sci. 91, 3847-3858.

Searle, S.R., Casella, G., McCulloch, C.E., 1992. Variance components. John Wiley \& Sons, New York, USA.

Seo, J.K., Yang, J., Kim, H.J., Upadhaya, S.D., Cho, W.M., Ha, J.K., 2010. Effects of Synchronization of Carbohydrate and Protein Supply on Ruminal Fermentation, Nitrogen Metabolism and Microbial Protein Synthesis in Holstein Steers. Asianaustralas. J. Anim. Sci. 23, 1455-1461.

Sniffen, C.J., Robinson, P.H., 1987. Protein and fiber digestion, passage and utilization in lactating cows. Microbial growth and flow as influenced by dietary manipulations. J. Dairy Sci. 70, 425-441. 
Stergiadis, S., Allen, M., Chen, X., Wills, D., Yan, T., 2015a. Prediction of metabolisable energy concentrations of fresh-cut grass using digestibility data measured with nonpregnant non-lactating cows. Br. J. Nutr. 113, 1571-1584.

Stergiadis, S., Chen, X.J., Allen, M., Wills, D., Yan, T., 2015b. Evaluating nitrogen utilization efficiency of nonpregnant dry cows offered solely fresh cut grass at maintenance levels. J. Anim. Sci. 93, 709-720.

Stergiadis, S., Zou, C., Chen, X., Allen, M., Wills, D., Yan, T., 2016. Equations to predict methane emissions from cows fed at maintenance energy level in pasture-based systems. Agric. Ecosyst. Environ. 220, 8-20.

Storm, E., Ørskov, E.R., 2007. The nutritive value of rumen micro-organisms in ruminants. 1. Large-scale isolation and chemical composition of rumen micro-organisms. Br. J. Nutr. $50,463-470$.

Stouthamer, A.H., 1973. A theoretical study on the amount of ATP required for synthesis of microbial cell material. Antonie van Leeuwenhoek 39, 545-565.

Tamminga, S., 1992. Nutrition management of dairy cows as a contribution to pollution control. J. Dairy Sci. 75, 345-357.

Tamminga, S., 2006. Environmental impacts of beef cattle. The John M. Airy symposium: Visions for animal agriculture and the environment, Kansas City, Missouri.

Tas, B.M., Taweel, H.Z., Smit, H.J., Elgersma, A., Dijkstra, J., Tamminga, S., 2006. Effects of perennial ryegrass cultivars on milk yield and nitrogen utilization in grazing dairy cows. J. Dairy Sci. 89, 3494-3500.

van der Weerden, T.J., Luo, J., de Klein, C.A.M., Hoogendoorn, C.J., Littlejohn, R.P., Rys, G.J., 2011. Disaggregating nitrous oxide emission factors for ruminant urine and dung deposited onto pastoral soils. Agric. Ecosyst. Environ. 141, 426-436. 
Varel, V.H., Nienaber, J.A., Freetly, H.C., 1999. Conservation of nitrogen in cattle feedlot waste with urease inhibitors. J. Anim. Sci. 77, 1162-1168.

Vasconcelos, J.T., Cole, N.A., McBride, K.W., Gueye, A., Galyean, M.L., Richardson, C.R., Greene, L.W., 2009. Effects of dietary crude protein and supplemental urea levels on nitrogen and phosphorus utilization by feedlot cattle. J. Anim. Sci. 87, 1174-1183.

VSN International, 2013. GenStat for Windows 16th Edition. VSN International, Hemel Hempstead, UK.

Waldrip, H.M., Todd, R.W., Cole, N.A., 2013. Prediction of nitrogen excretion by beef cattle: A meta-analysis. J. Anim. Sci. 91, 4290-4302.

Weiss, W.P., Chamberlain, D.G., Hunt, C.W., 2003. Feeding Silages. In: Buxton, D.R., Muck, R.E., Harrison, J.H. (Eds.), Silage Science and Technology. American Society of Agronomy, Crop Science Society of America, Soil Science Society of America, Madison, WI, pp. 469-504.

Yan, T., Frost, J.P., Agnew, R.E., Binnie, R.C., Mayne, C.S., 2006. Relationships among manure nitrogen output and dietary and animal factors in lactating dairy cows. J. Dairy Sci. 89, 3981-3991.

Yan, T., Frost, J.P., Keady, T.W., Agnew, R.E., Mayne, C.S., 2007. Prediction of nitrogen excretion in feces and urine of beef cattle offered diets containing grass silage. J. Anim. Sci. 85, 1982-1989.

Zhang, X., Zhang, H., Wang, Z., Zhang, X., Zou, H., Tan, C., Peng, Q., 2015. Effects of dietary carbohydrate composition on rumen fermentation characteristics and microbial population in vitro. Ital. J. Anim. Sci. 14, 3366. 
Fig. 1 Relationships between urine nitrogen output, expressed per manure nitrogen output and (a) nitrogen intake (NI) (b) nitrogen apparent digestibility (Nd), and (c) diet nitrogen content (N). $\mathrm{R}^{2}$ and MPE represent pseudo correlation coefficient and mean prediction error, respectively. MPE derived from an internal validation with new equations, listed in Table A2.

Fig. 2 Bland-Altman plots showing the agreement between actual manure nitrogen output (MNO) and predicted from equations shown by Yan et al. (2007) (panels b, d and f) or developed in the current study by using either the same explanatory variables (panels a, c and e, respectively) or newly introduced ones (panels $g$ and $h$ ). In order to predict MNO, the following were used as predictors: (i) nitrogen intake (NI) for panels a and b, (ii) NI and bodyweight (BW) for panels c and d, (iii) NI, BW and diet forage proportion for e and f, (iv) NI and dry matter apparent digestibility for panel g, and (v) NI, BW and metabolisable energy intake for panel h. Prediction equations are shown in Table A1 (for panels a, c, e, g and h) and Table A3 (for panels b, d and f). Residual represents the difference between predicted minus actual value. Rc is Lin's concordance correlation coefficient with $95 \%$ confidence interval given in square brackets.

Fig. 3 Bland-Altman plots showing the agreement between actual urine nitrogen output (UNO) and predicted from equations shown by Waldrip et al. (2013) (panel b), Reed et al. (2015) (panel d) or developed in the current study by using either the same explanatory variables (panels a and c respectively) or newly introduced ones (panels e and f). In order to predict UNO, the following were used as predictors: (i) nitrogen intake (NI) for panels a and b, (ii) body weight and diet crude protein for panels c and d, (iii) NI, diet nitrogen content (N), diet neutral-detergent fibre and dry matter apparent digestibility for panel e, and (iv) dry matter intake, $\mathrm{N}$ and diet gross energy for panel f. Prediction equations are shown in Table A1 (for panels a, c, e and f) and Table A3 (for panels b and d). Residual represents the difference between predicted minus actual value. Rc is Lin's concordance correlation coefficient with $95 \%$ confidence interval given in square brackets.

Fig. 4 Bland-Altman plots showing the agreement between actual faeces nitrogen output (FNO) and predicted from equations shown by Dong et al. (2014) (panel b), Hirooka (2010) (panel d) or developed in the current study by using either the same explanatory variables (panels a and c respectively) or newly introduced ones (panels e and f). In order to predict FNO, the following were used as predictors: (i) nitrogen intake (NI) for panels a and b, (ii) dry matter intake (DMI) for panels c and d, (iii) DMI, diet nitrogen content (N) and dry matter apparent digestibility for panel e, and (iv) NI, N and diet neutral-detergent fibre for panel f. Prediction equations are shown in Table A1 (for panels a, c, e and f) and Table A3 (for panels b and d). Residual represents the difference between predicted minus actual value. Rc is Lin's concordance correlation coefficient with $95 \%$ confidence interval given in square brackets. 


\section{Tables}

Table 1 Description of data collected from 69 published studies, used to predict $\mathrm{N}$ excretion, including body weight, diet chemical composition and energy contents, nutrient intakes, $\mathrm{N}$ outputs and $\mathrm{N}$ use efficiency parameters and $\mathrm{N}$ outputs

\begin{tabular}{|c|c|c|c|c|c|}
\hline Parameters assessed & Mean \pm SD & Min & $\operatorname{Max}$ & $\mathrm{CV}$ & $\mathrm{n}$ \\
\hline \multicolumn{6}{|l|}{ Animal data } \\
\hline Body weight (kg) & $363 \pm 123.1$ & 66 & 600 & 0.34 & 272 \\
\hline \multicolumn{6}{|c|}{ Diet chemical composition ( $\mathrm{g} / \mathrm{kg}$ DM) } \\
\hline Total forage (g/100g DM) & $38.7 \pm 30.08$ & 0 & 100 & 0.77 & 289 \\
\hline $\mathrm{DM}(\mathrm{g} / \mathrm{kg}$ fresh $)$ & $678.4 \pm 197.1$ & 104.9 & 925.0 & 0.29 & 172 \\
\hline $\mathrm{OM}$ & $938.1 \pm 15.70$ & 876.6 & 974.0 & 0.02 & 216 \\
\hline $\mathrm{CP}$ & $139.2 \pm 36.42$ & 47.0 & 268.8 & 0.26 & 289 \\
\hline $\mathrm{N}$ & $22.3 \pm 5.828$ & 7.5 & 43.0 & 0.26 & 289 \\
\hline $\mathrm{EE}$ & $39.1 \pm 18.38$ & 10.0 & 109.0 & 0.47 & 149 \\
\hline NDF & $346.1 \pm 144.3$ & 99.0 & 784.0 & 0.42 & 223 \\
\hline $\mathrm{ADF}$ & $205.6 \pm 96.77$ & 49.0 & 418.2 & 0.47 & 166 \\
\hline Starch & $382.3 \pm 135.3$ & 97.3 & 662.2 & 0.35 & 74 \\
\hline Ash & $61.1 \pm 15.39$ & 26.0 & 123.4 & 0.25 & 208 \\
\hline \multicolumn{6}{|l|}{ Diet energy contents (MJ/kg DM) } \\
\hline GE & $18.2 \pm 1.00$ & 14.8 & 19.3 & 0.05 & 66 \\
\hline $\mathrm{ME}$ & $11.0 \pm 1.77$ & 6.3 & 13.2 & 0.16 & 47 \\
\hline \multicolumn{6}{|c|}{ Nutrient $(\mathrm{kg} / \mathrm{d})$ and energy $(\mathrm{MJ} / \mathrm{d})$ intakes } \\
\hline DM intake & $7.22 \pm 2.186$ & 1.80 & 13.1 & 0.30 & 289 \\
\hline OM intake & $6.96 \pm 1.921$ & 1.60 & 11.0 & 0.28 & 211 \\
\hline CP intake & $1.00 \pm 0.419$ & 0.22 & 2.21 & 0.42 & 289 \\
\hline $\mathrm{N}$ intake (g/d) & $160.2 \pm 67.18$ & 35.9 & 353.0 & 0.42 & 289 \\
\hline NDF intake & $2.48 \pm 1.229$ & 0.52 & 6.68 & 0.49 & 218 \\
\hline ADF intake & $1.41 \pm 0.778$ & 0.20 & 3.50 & 0.55 & 161 \\
\hline Starch intake & $3.06 \pm 1.365$ & 0.69 & 5.58 & 0.45 & 74 \\
\hline GE intake & $128.7 \pm 44.82$ & 52.3 & 215.9 & 0.35 & 66 \\
\hline ME intake & $77.0 \pm 24.85$ & 37.6 & 112.0 & 0.32 & 47 \\
\hline \multicolumn{6}{|l|}{ Diet apparent digestibility } \\
\hline DM apparent digestibility (g/kg) & $694.8 \pm 75.42$ & 466.0 & 850.0 & 0.11 & 199 \\
\hline OM apparent digestibility ( $\mathrm{g} / \mathrm{kg}$ ) & $713.1 \pm 82.11$ & 467.5 & 876.0 & 0.12 & 167 \\
\hline $\mathrm{N}$ apparent digestibility $(\mathrm{g} / \mathrm{kg})$ & $669.2 \pm 98.63$ & 251.0 & 869.0 & 0.15 & 266 \\
\hline \multicolumn{6}{|l|}{ Nitrogen output and retention $(\mathrm{g} / \mathrm{d})$} \\
\hline Manure N output & $121.5 \pm 58.68$ & 23.8 & 303.0 & 0.48 & 268 \\
\hline Urine $\mathrm{N}$ output & $67.7 \pm 42.54$ & 4.3 & 201.0 & 0.63 & 254 \\
\hline Faeces N output & $47.8 \pm 15.57$ & 14.4 & 101.9 & 0.33 & 271 \\
\hline Retained N & $41.7 \pm 20.20$ & 4.0 & 123.0 & 0.48 & 263 \\
\hline \multicolumn{6}{|c|}{ Nitrogen use efficiency parameters $(\mathrm{kg} / \mathrm{kg})$} \\
\hline Manure $\mathrm{N}: \mathrm{N}$ intake & $0.731 \pm 0.1039$ & 0.330 & 0.964 & 0.14 & 267 \\
\hline Urine $\mathrm{N}: \mathrm{N}$ intake & $0.403 \pm 0.1127$ & 0.129 & 0.758 & 0.28 & 253 \\
\hline Faeces $\mathrm{N}: \mathrm{N}$ intake & $0.330 \pm 0.0963$ & 0.131 & 0.755 & 0.29 & 270 \\
\hline Retained $\mathrm{N}: \mathrm{N}$ intake & $0.266 \pm 0.0993$ & 0.036 & 0.497 & 0.37 & 262 \\
\hline Urine $\mathrm{N}$ : Manure $\mathrm{N}$ & $0.548 \pm 0.1144$ & 0.254 & 0.853 & 0.21 & 251 \\
\hline Faeces $\mathrm{N}$ : Manure $\mathrm{N}$ & $0.452 \pm 0.1140$ & 0.147 & 0.746 & 0.25 & 251 \\
\hline Faeces $\mathrm{N}$ : Urine $\mathrm{N}$ & $0.913 \pm 0.4595$ & 0.173 & 2.944 & 0.50 & 251 \\
\hline
\end{tabular}


organic matter; $\mathrm{CP}=$ crude protein; $\mathrm{N}=$ nitrogen; $\mathrm{EE}=$ ether extract; $\mathrm{NDF}=$ neutral-detergent fibre; $\mathrm{ADF}=$ acid-detergent fibre; $\mathrm{GE}=$ gross energy; $\mathrm{ME}=$ metabolisable energy . 
Table 2 Single and multiple linear prediction of nitrogen excretion in manure, urine and faeces using intakes of feed, nutrient and energy, or body weight, diet chemical composition, energy contents and forage proportion, and apparent total tract digestibility.

\begin{tabular}{|c|c|c|c|c|c|c|}
\hline & & Equations $^{\mathrm{a}}$ & $\mathrm{n}$ & $\mathrm{R}^{2}$ & $\mathrm{MPE}^{\mathrm{b}}$ & Eq. \\
\hline \multirow[t]{16}{*}{$\mathrm{MNO}=$} & $-14.42_{(11.553)}$ & $+18.27_{(1.594)}$ DMI & 243 & 0.83 & 0.440 & (1a) \\
\hline & $-113.5_{(8.82)}$ & $+17.96_{(1.012)} \mathrm{DMI}+4.494_{(0.2099)} \mathrm{N}$ & 243 & 0.95 & 0.296 & (1b) \\
\hline & $-273.0_{(76.26)}$ & $+20.03_{(2.021)} \mathrm{DMI}+3.880_{(0.4877)} \mathrm{N}+8.964_{(4.1790)} \mathrm{GE}$ & 59 & 0.92 & 0.290 & (1c) \\
\hline & $-5.681_{(3.1652)}$ & $+0.761_{(0.0157)} \mathrm{NI}$ & 243 & 0.98 & 0.201 & (1d) \\
\hline & $-10.32_{(3.743)}$ & $+0.766_{(0.0157)} \mathrm{NI}+0.108_{(0.0485)} \mathrm{TF}$ & 242 & 0.98 & 0.195 & (1e) \\
\hline & $-12.95(5.110)$ & $+0.750_{(0.0183)} \mathrm{NI}+0.054_{(0.0189)} \mathrm{ADF}$ & 148 & 0.98 & 0.178 & (1f) \\
\hline & $30.70_{(14.310)}$ & $+0.742_{(0.0194)} \mathrm{NI}-0.048_{(0.0204)} \mathrm{DMd}$ & 179 & 0.98 & 0.162 & $(1 \mathrm{~g})$ \\
\hline & $29.99_{(12.901)}$ & $+0.222_{(0.0320)} \mathrm{BW}$ & 226 & 0.82 & 0.557 & (1h) \\
\hline & $-83.40_{(10.162)}$ & $+0.221_{(0.0196)} \mathrm{BW}+5.179_{(0.2158)} \mathrm{N}$ & 226 & 0.96 & 0.449 & (1i) \\
\hline & $-109.2_{(16.04)}$ & $+0.235_{(0.0301)} \mathrm{BW}+5.307_{(0.2483)} \mathrm{N}+0.099_{(0.0352)} \mathrm{ADF}$ & 134 & 0.96 & 0.356 & $(1 \mathrm{j})$ \\
\hline & $-93.60_{(16.199)}$ & $+0.239_{(0.0280)} \mathrm{BW}+5.161_{(0.2479)} \mathrm{N}+0.226_{(0.0587)} \mathrm{ADF}-0.109_{(0.0403)} \mathrm{NDF}$ & 134 & 0.97 & 0.350 & $(1 \mathrm{k})$ \\
\hline & $-9.167_{(5.6199)}$ & $-0.631_{(1.0443)} \mathrm{DMI}+0.755_{(0.0185)} \mathrm{NI}+0.025_{(0.0159)} \mathrm{BW}$ & 226 & 0.98 & 0.202 & $(11)^{\mathrm{c}}$ \\
\hline & $-26.65_{(36.268)}$ & $+0.324_{(0.1409)} \mathrm{NI}-1.251_{(2.7121)} \mathrm{ME}+0.285_{(0.1794)} \mathrm{CP}+0.180_{(0.0477)} \mathrm{BW}$ & 37 & 0.97 & 0.193 & $(1 \mathrm{~m})^{\mathrm{c}}$ \\
\hline & $-15.01_{(11.513)}$ & $+0.530_{(0.0678)} \mathrm{NI}+0.124_{(0.0473)} \mathrm{BW}-0.021_{(0.2662)} \mathrm{MEI}$ & 37 & 0.97 & 0.172 & $(1 \mathrm{n})^{\mathrm{c}}$ \\
\hline & $-10.67_{(4.816)}$ & $+0.752_{(0.0174)} \mathrm{NI}+0.019_{(0.0125)} \mathrm{BW}$ & 226 & 0.98 & 0.202 & $(10)^{\mathrm{c}}$ \\
\hline & $-15.77_{(5.314)}$ & $+0.757_{(0.0176)} \mathrm{NI}+0.020_{(0.0126)} \mathrm{BW}+0.105_{(0.0514)} \mathrm{TF}$ & 225 & 0.98 & 0.194 & $(1 \mathrm{p})^{\mathrm{c}}$ \\
\hline \multirow[t]{14}{*}{$\mathrm{UNO}=$} & $-10.47_{(12.346)}$ & $+11.13_{(1.526)} \mathrm{DMI}$ & & & 0.702 & $(2 \mathrm{a})$ \\
\hline & $-95.69_{(9.522)}$ & $+10.87_{(0.975)} \mathrm{DMI}+3.853_{(0.1809)} \mathrm{N}$ & 239 & 0.9 & 0.480 & $(2 b)$ \\
\hline & $-82.67_{(11.773)}$ & $+11.21_{(1.169)} \mathrm{DMI}+3.792_{(0.2102)} \mathrm{N}-0.137_{(0.0332)} \mathrm{NDF}+0.171_{(0.0508)} \mathrm{ADF}$ & 148 & 0.95 & 0.459 & $(2 c)$ \\
\hline & $-241.2(64.780)$ & $+13.59_{(1.789)} \mathrm{DMI}+3.130_{(0.3917)} \mathrm{N}+7.947_{(3.4765)} \mathrm{GE}$ & 59 & 0.92 & 0.440 & $(2 \mathrm{~d})$ \\
\hline & $-26.49_{(3.117)}$ & $+0.597_{(0.0158)} \mathrm{NI}$ & 239 & 0.97 & 0.348 & $(2 \mathrm{e})$ \\
\hline & $-97.75_{(22.853)}$ & $+0.432_{(0.0342)} \mathrm{NI}+1.330_{(0.2878)} \mathrm{N}+0.036_{(0.0152)} \mathrm{NDF}+0.075_{(0.0280)} \mathrm{DMd}$ & 146 & 0.97 & 0.304 & $(2 \mathrm{f})$ \\
\hline & $-113.0_{(23.10)}$ & $+0.480_{(0.0413)} \mathrm{NI}+1.049_{(0.3447)} \mathrm{N}+0.042_{(0.0154)} \mathrm{NDF}+0.090_{(0.0275)} \mathrm{OMd}$ & 134 & 0. & 0.296 & $(2 \mathrm{~g})$ \\
\hline & $15.22_{(13.718)}$ & $+0.146_{(0.0300)} \mathrm{BW}$ & 222 & 0.79 & 0.741 & (2h) \\
\hline & $-80.88_{(11.132)}$ & $+0.138_{(0.0177)} \mathrm{BW}+4.455_{(0.1628)} \mathrm{N}$ & 222 & & 0.542 & $(2 \mathrm{i})$ \\
\hline & $-90.64_{(12.556)}$ & $+0.163_{(0.0219)} \mathrm{BW}+4.460_{(0.1813)} \mathrm{N}-0.102_{(0.0297)} \mathrm{NDF}+0.173_{(0.0433)} \mathrm{ADF}$ & 134 & 0.97 & 0.429 & $(2 \mathrm{j})$ \\
\hline & $229.0_{(86.28)}$ & $+0.301_{(0.0157)} \mathrm{BW}+4.364_{(0.8107)} \mathrm{N}+0.088_{(0.0288)} \mathrm{Starch}-30.38_{(7.919)} \mathrm{ME}$ & 19 & 0.99 & 0.208 & $(2 \mathrm{k})$ \\
\hline & $-16.89_{(20.602)}$ & $+3.770_{(0.2054)} \mathrm{N}$ & 239 & 0.92 & 0.764 & $(21)^{\mathrm{c}}$ \\
\hline & $-10.74_{(4.771)}$ & $-3.227_{(0.7512)} \mathrm{DMI}+0.637_{(0.0179)} \mathrm{NI}$ & 239 & 0.97 & 0.345 & $(2 \mathrm{~m})^{\mathrm{c}}$ \\
\hline & $-44.99(7.372)$ & $+0.439_{(0.0370)} \mathrm{NI}+0.032_{(0.0163)} \mathrm{BW}+0.232_{(0.0459)} \mathrm{CP}$ & 222 & 0.97 & 0.352 & $(2 n)^{c}$ \\
\hline \multirow[t]{18}{*}{$\mathrm{FNO}=$} & $1.630_{(4.6310)}$ & $+6.378_{(0 .}$ & & 0.8 & 0.338 & (3a) \\
\hline & $-12.11_{(4.840)}$ & $+6.461_{(0.4442)} \mathrm{DMI}+0.593_{(0.0778)} \mathrm{N}$ & 56 & & 316 & $(3 b)$ \\
\hline & $-11.65_{(4.751)}$ & $+6.043_{(0.4990)} \mathrm{DMI}+0.592_{(0.0934)} \mathrm{N}+0.025_{(0.0109)} \mathrm{ADF}$ & 159 & 0.90 & 0.259 & $(3 c)$ \\
\hline & $-19.12(5.202)$ & $+6.733_{(0.4595)} \mathrm{DMI}+0.644_{(0.0856)} \mathrm{N}+0.015_{(0.0063)} \mathrm{NDF}$ & 200 & 0.90 & 0.268 & $(3 \mathrm{~d})$ \\
\hline & $5.693_{(10.5960)}$ & $+6.687_{(0.8208)} \mathrm{DMI}+1.165_{(0.2184)} \mathrm{N}-1.664_{(0.5616)} \mathrm{GE}$ & 59 & 0.83 & 0.247 & $(3 \mathrm{e})$ \\
\hline & $-64.37_{(32.339)}$ & $+5.424_{(0.9081)} \mathrm{DMI}-0.787_{(0.1462)} \mathrm{N}+7.463_{(2.2544)} \mathrm{GE}-3.445_{(1.3883)} \mathrm{ME}$ & 15 & 0.99 & 0.177 & $(3 f)$ \\
\hline & $27.44_{(7.657)}$ & $+7.316_{(0.4025)} \mathrm{DMI}+0.811_{(0.0861)} \mathrm{N}-0.069_{(0.0099)} \mathrm{DMd}$ & 190 & 0.93 & 0.201 & $(3 g)$ \\
\hline & $42.53_{(9.918)}$ & $+6.953_{(0.5935)} \mathrm{DMI}+0.910_{(0.0955)} \mathrm{N}-0.090_{(0.0128)} \mathrm{OMd}$ & 158 & 0.91 & 0.269 & (3h) \\
\hline & $21.94_{(2.061)}$ & $+0.158_{(0.0103)} \mathrm{NI}$ & 256 & 0.90 & 0.328 & $(3 \mathrm{i})$ \\
\hline & $17.10_{(2.427)}$ & $+0.163_{(0.0103)} \mathrm{NI}+0.105_{(0.0297)} \mathrm{TF}$ & 256 & 0. & 0.301 & $(3 \mathrm{j})$ \\
\hline & $-127.6_{(43.49)}$ & $+0.184_{(0.0113)} \mathrm{NI}+0.186_{(0.0294)} \mathrm{TF}+0.148_{(0.0455)} \mathrm{OM}$ & 197 & 0.88 & 0.261 & $(3 \mathrm{k})$ \\
\hline & $27.67_{(2.832)}$ & $+0.240_{(0.0151)} \mathrm{NI}-0.838_{(0.1164)} \mathrm{N}$ & 256 & 0. & 0.304 & $(31)$ \\
\hline & $18.83_{(3.132)}$ & $+0.250_{(0.0148)} \mathrm{NI}-0.910_{(0.1209)} \mathrm{N}+0.030_{(0.0057)} \mathrm{NDF}$ & 200 & 0.92 & 0.245 & $(3 \mathrm{~m})$ \\
\hline & $75.78(8.141)$ & $+0.181_{(0.0119)} \mathrm{NI}-0.080_{(0.0117)} \mathrm{DMd}$ & 190 & 0.91 & 0.262 & $(3 n)$ \\
\hline & $80.67_{(9.538)}$ & $+0.162_{(0.0125)} \mathrm{NI}-0.081_{(0.0134)} \mathrm{OMd}$ & 158 & & 0.293 & (3o) \\
\hline & $22.51_{(3.773)}$ & $+0.066_{(0.0095)} \mathrm{BW}$ & 239 & 0.84 & 0.409 & $(3 p)$ \\
\hline & $6.934_{(4.2396)}$ & $+0.067_{(0.0095)} \mathrm{BW}+0.693_{(0.1013)} \mathrm{N}$ & 239 & 0.88 & 0.397 & $(3 q)$ \\
\hline & $33.70_{(5.885)}$ & $+0.579_{(0.1035)} \mathrm{N}$ & 256 & 0.84 & 0.458 & $(3 r)^{c}$ \\
\hline
\end{tabular}

$\mathrm{n}=$ number of observations; $\mathrm{R}^{2}=$ pseudo correlation coefficient; $\mathrm{MPE}=$ mean prediction error; Eq. $=$ equation; $\mathrm{MNO}=$ manure nitrogen output; DMI = dry matter intake; $\mathrm{N}=$ diet nitrogen content; GE = diet gross energy content; $\mathrm{NI}=$ nitrogen intake; $\mathrm{TF}=$ diet forage proportion; $\mathrm{ADF}=$ diet acid-detergent fibre content; $\mathrm{DMd}=$ dry matter apparent digestibility; $\mathrm{BW}$ = body weight; $\mathrm{NDF}=$ diet neutral-detergent fibre content; $\mathrm{CP}=$ diet crude protein content; $\mathrm{MEI}=$ metabolisable energy intake; UNO = urine nitrogen output; OMd = organic matter apparent digestibility; $\mathrm{ME}=$ diet metabolisable energy 
content; $\mathrm{FNO}=$ faeces nitrogen output; $\mathrm{OM}=$ diet organic matter content.

${ }^{a}$ Units: g/d for MNO, UNO, FNO; kg/d for DMI; g/kg DM for N, NDF, ADF, CP, Starch, OM; MJ/kg DM for GE, ME; $\mathrm{g} / \mathrm{d}$ for NI; g/100g DM for TF; g/kg for DMd, OMd; MJ/d for MEI. The effect of all explanatory variables was significant according to the Wald statistic (Fpr $<0.05$ ), except from equations 11 (Fpr $>0.05$ for BW), $1 \mathrm{~m}$ (Fpr $>0.05$ for ME, CP), $1 \mathrm{n}$ (Fpr $>0.05$ for MEI), 1o (Fpr $>0.05$ for BW) and 1p (Fpr $>0.05$ for TF) and $2 \mathrm{n}$ (Fpr $>0.05$ for BW), which were only developed to include the same predictors as external equations. The random effects of the individual study and animal breed were accounted for all predicted variables, while for the prediction of UNO and FNO, the production stage of the animals was also included to the model, according to changes in deviance during the development of the random model.

${ }^{\mathrm{b}}$ MPE derived from an internal validation (details presented in Table 4), with new equations, listed in Table A1, which were developed from the two-thirds of the whole database and by using the exact model presented in the current table; the new equations were validated against the remaining one-third of the whole database.

${ }^{\mathrm{c}}$ Equations 11-1p, 21-2n and 3r, were developed to include the same predictors as external equations E6 (11), E9 (1m), E7 (1n), E5 (1o), E8 (1p), E14 (21), E15 (21), E16 (2m), E17 (2n), E22 (3r) and E23 (3r), shown in Table A3. 
Table 3 Single and multiple linear prediction of urine nitrogen output and retained nitrogen, both expressed per nitrogen intake, and urine nitrogen output, expressed per manure nitrogen output, using intakes of feed and nutrient, or body weight, diet chemical composition and apparent total tract digestibility and diet chemical composition.

\begin{tabular}{|c|c|c|c|c|c|c|}
\hline & & Equations $^{\mathrm{a}}$ & $\mathrm{n}$ & $\mathrm{R}^{2}$ & $\mathrm{MPE}^{\mathrm{b}}$ & Eq. \\
\hline $\begin{array}{l}\text { UNO/NI } \\
\left(\times 10^{3}\right)\end{array}$ & $\begin{aligned} & 291.2_{(33.72)} \\
& 120.0_{(35.30)} \\
- & 189.4_{(48.45)} \\
- & 230.0_{(51.80)} \\
& 251.2_{(19.27)} \\
& 218.6_{(21.75)} \\
- & 8.287_{(88.3750} \\
- & 406.4_{(144.18)} \\
- & 116.1_{(99.11)} \\
- & 479.7_{(142.74)} \\
& 106.5_{(33.06)} \\
- & 192.6_{(47.85)} \\
& 230.5_{(22.53)} \\
- & 118.6_{(43.90)}\end{aligned}$ & $\begin{array}{l}+15.93_{(4.641)} \mathrm{DMI} \\
+16.12_{(4.074)} \mathrm{DMI}+7.533_{(0.8206)} \mathrm{N} \\
+12.20_{(3.825)} \mathrm{DMI}+0.735_{(0.0612)} \mathrm{Nd} \\
+11.86_{(3.786)} \mathrm{DMI}+0.765_{(0.0628)} \mathrm{Nd}+0.598_{(0.2809)} \mathrm{TF} \\
+0.977_{(0.1016)} \mathrm{NI} \\
+0.653_{(0.1457)} \mathrm{NI}+3.620_{(1.8370)} \mathrm{N} \\
+0.785_{(0.1233)} \mathrm{NI}+0.37_{(0.1260)} \mathrm{DMd} \\
+0.699_{(0.1215)} \mathrm{NI}+0.829_{(0.1756)} \mathrm{DMd}+0.323_{(0.0946)} \mathrm{NDF} \\
+0.850_{(0.1161)} \mathrm{NI}+0.516_{(0.1391)} \mathrm{OMd} \\
+0.790_{(0.1155)} \mathrm{NI}+0.882_{(0.1710)} \mathrm{OMd}+0.323_{(0.0943)} \mathrm{NDF} \\
+0.288_{(0.0699)} \mathrm{BW}+8.734_{(0.8658)} \mathrm{N} \\
+0.231_{(0.0663)} \mathrm{BW}+0.743_{(0.0609)} \mathrm{Nd} \\
+7.470_{(0.8385)} \mathrm{N} \\
+0.754_{(0.0619)} \mathrm{Nd}\end{array}$ & $\begin{array}{l}238 \\
238 \\
231 \\
231 \\
238 \\
238 \\
180 \\
145 \\
144 \\
133 \\
221 \\
214 \\
238 \\
231\end{array}$ & $\begin{array}{l}0.77 \\
0.84 \\
0.87 \\
0.87 \\
0.84\end{array}$ & $\begin{array}{l}0.367 \\
0.343 \\
0.311 \\
0.300 \\
0.338 \\
0.337 \\
0.325 \\
0.323 \\
0.320 \\
0.320 \\
0.329 \\
0.313 \\
0.370 \\
0.333\end{array}$ & $\begin{array}{l}(4 \mathrm{a}) \\
(4 \mathrm{~b}) \\
(4 \mathrm{c}) \\
(4 \mathrm{~d}) \\
(4 \mathrm{e}) \\
(4 \mathrm{f}) \\
(4 \mathrm{~g}) \\
(4 \mathrm{~h}) \\
(4 \mathrm{i}) \\
(4 \mathrm{j}) \\
(4 \mathrm{k}) \\
(4 \mathrm{l}) \\
(4 \mathrm{~m}) \\
(4 \mathrm{n})\end{array}$ \\
\hline $\begin{array}{l}\mathrm{RN} / \mathrm{NI} \\
\left(\mathrm{x} 10^{3}\right)\end{array}$ & $\begin{aligned} & 349.0_{(29.61)} \\
& 379.1_{(30.61)} \\
& 190.2_{(48.41)} \\
& 244.9_{(56.31)} \\
& 267.4_{(59.75)} \\
& 383.8_{(30.30)} \\
& 192.4_{(47.88)} \\
& 119.1_{(43.80)}\end{aligned}$ & $\begin{array}{l}-10.34_{(3.906)} \mathrm{DMI} \\
-10.24_{(3.818)} \mathrm{DMI}-0.827_{(0.2834)} \mathrm{TF} \\
-12.20_{(3.825)} \mathrm{DMI}+0.264_{(0.0611)} \mathrm{Nd} \\
-15.44_{(4.434)} \mathrm{DMI}+0.305_{(0.0649)} \mathrm{Nd}-0.370_{(0.1036)} \mathrm{ADF} \\
-11.32_{(3.982)} \mathrm{DMI}+0.238_{(0.0659)} \mathrm{Nd}-0.195_{(0.0636)} \mathrm{NDF} \\
-0.219_{(0.0679)} \mathrm{BW}-0.752_{(0.2953)} \mathrm{TF} \\
-0.228_{(0.0664)} \mathrm{BW}+0.255_{(0.0609)} \mathrm{Nd} \\
+0.245_{(0.0618)} \mathrm{Nd}\end{array}$ & $\begin{array}{l}237 \\
237 \\
228 \\
139 \\
180 \\
220 \\
211 \\
228\end{array}$ & $\begin{array}{l}0.83 \\
0.86\end{array}$ & $\begin{array}{l}0.470 \\
0.458 \\
0.456 \\
0.464 \\
0.459 \\
0.469 \\
0.457 \\
0.490\end{array}$ & $\begin{array}{l}(5 \mathrm{a}) \\
(5 \mathrm{~b}) \\
(5 \mathrm{c}) \\
(5 \mathrm{~d}) \\
(5 \mathrm{e}) \\
(5 \mathrm{f}) \\
(5 \mathrm{~g}) \\
(5 \mathrm{~h})\end{array}$ \\
\hline $\begin{array}{l}\text { UNO/MNO } \\
\left(\times 10^{3}\right)\end{array}$ & $\begin{array}{r}436.5_{(35.76)} \\
194.5_{(34.83)} \\
261.6_{(51.18)} \\
-319.4_{(35.70)} \\
350.1_{(19.43)} \\
-249.0_{(99.26)} \\
439.3_{(31.92)} \\
489 . ._{(34.30)} \\
171.4_{(32.18)} \\
234.7_{(56.15)} \\
-321.9_{(34.93)} \\
299.1_{(22.54)} \\
-281.1_{(32.89)}\end{array}$ & $\begin{array}{l}+16.10_{(4.964)} \mathrm{DMI} \\
+15.33_{(3.990)} \mathrm{DMI}+10.98_{(0.853)} \mathrm{N} \\
+17.87_{(4.971)} \mathrm{DMI}+10.41_{(0.942)} \mathrm{N}-0.540_{(0.1450)} \mathrm{NDF}+0.552_{(0.2193)} \mathrm{ADF} \\
+6.960_{(2.7316)} \mathrm{DMI}+1.199_{(0.0467)} \mathrm{Nd} \\
+1.290_{(0.1063)} \mathrm{NI} \\
+1.232_{(0.1232)} \mathrm{NI}+0.812_{(0.1385)} \mathrm{OMd} \\
+0.304_{(0.0853)} \mathrm{BW} \\
+0.288_{(0.0814)} \mathrm{BW}-1.115_{(0.3399)} \mathrm{TF} \\
+0.275_{(0.0671)} \mathrm{BW}+12.50_{(0.893)} \mathrm{N} \\
+0.317_{(0.0849)} \mathrm{BW}+12.14_{(1.017)} \mathrm{N}-0.486_{(0.1454)} \mathrm{NDF}+0.462_{(0.2025)} \mathrm{ADF} \\
+0.150_{(0.0465)} \mathrm{BW}+1.196_{(0.0467)} \mathrm{Nd} \\
+10.95_{(0.868)} \mathrm{N} \\
+1.214_{(0.0469)} \mathrm{Nd}\end{array}$ & $\begin{array}{l}236 \\
236 \\
147 \\
231 \\
236 \\
142 \\
219 \\
219 \\
219 \\
133 \\
214 \\
236 \\
231\end{array}$ & $\begin{array}{l}0.69 \\
0.83 \\
0.86 \\
0.92 \\
0.82 \\
0.88 \\
0.70\end{array}$ & $\begin{array}{l}0.287 \\
0.249 \\
0.239 \\
0.150 \\
0.256 \\
0.216 \\
0.275 \\
0.244 \\
0.267 \\
0.212 \\
0.148 \\
0.265 \\
0.158\end{array}$ & $\begin{array}{l}(6 \mathrm{a}) \\
(6 \mathrm{~b}) \\
(6 \mathrm{c}) \\
(6 \mathrm{~d}) \\
(6 \mathrm{e}) \\
(6 \mathrm{f}) \\
(6 \mathrm{~g}) \\
(6 \mathrm{~h}) \\
(6 \mathrm{i}) \\
(6 \mathrm{j}) \\
(6 \mathrm{k}) \\
(6 \mathrm{l}) \\
(6 \mathrm{~m})\end{array}$ \\
\hline
\end{tabular}

$\mathrm{n}=$ number of observations; $\mathrm{R}^{2}=$ pseudo correlation coefficient; MPE = mean prediction error; Eq. = equation; UNO = urine nitrogen output; $\mathrm{NI}=$ nitrogen intake; $\mathrm{DMI}=$ dry matter intake; $\mathrm{N}=$ diet nitrogen content; $\mathrm{Nd}=$ nitrogen apparent digestibility; $\mathrm{TF}=$ diet forage proportion; $\mathrm{DMd}=$ dry matter apparent digestibility; $\mathrm{NDF}=$ diet neutral detergent fibre content; OMd = organic matter apparent digestibility; $\mathrm{BW}=$ body weight; $\mathrm{RN}=$ retained nitrogen; $\mathrm{ADF}=$ diet acid-detergent fibre content; $\mathrm{MNO}=$ manure nitrogen output.

${ }^{\text {a } U n i t s: ~ g / g ~ f o r ~ U N O / N I, ~ R N / N I, ~ U N O / M N O ; ~ k g / d ~ f o r ~ D M I ; ~ g / k g ~ D M ~ f o r ~ N, ~ N D F, ~ A D F ; ~ g / k g ~ f o r ~ N d, ~ D M d, ~ O M d ; ~ g / 100 g ~ D M ~}$ for TF; g/d for NI; $\mathrm{kg}$ for BW. The effect of all explanatory variables was significant according to the Wald statistic (Fpr < 0.05). The random effects of the individual experiment and animal breed were accounted for all predicted variables, according to changes in deviance during the development of the random model.

b MPE derived from an internal validation (details shown in Table 5) with new equations, listed in Table A2, which were developed from the two-thirds of the whole database and by using the exact model presented in the current table; the new equations were validated against the remaining one-third of the whole database. 
Table 4 Internal validation using one-third of the whole data-set $(n=97)$ and equations developed from the remaining two-thirds of the whole data-set $(n=192)$.

\begin{tabular}{|c|c|c|c|c|c|c|c|c|c|c|c|}
\hline \multirow[b]{2}{*}{ Eq. $^{\mathrm{a}}$} & \multirow[b]{2}{*}{ Original Eq. } & \multirow[b]{2}{*}{ Predicted } & \multirow[b]{2}{*}{ Actual } & \multirow[b]{2}{*}{$\mathrm{r}^{2}$} & \multirow[b]{2}{*}{ MPE } & \multirow[b]{2}{*}{ SE } & \multirow[b]{2}{*}{$\mathrm{Rc}$} & \multicolumn{4}{|c|}{ Predicted - Actual } \\
\hline & & & & & & & & Mean & $\mathrm{SD}$ & Min & Max \\
\hline \multicolumn{12}{|c|}{ Manure nitrogen output $(\mathrm{g} / \mathrm{d})$} \\
\hline$(\mathrm{A} 1)$ & (1a) & 116.9 & 118.5 & 0.65 & 0.440 & 24.10 & 0.75 & -0.65 & 35.18 & -120.8 & 75.39 \\
\hline (A2) & $(1 b)$ & 113.1 & 118.5 & 0.84 & 0.296 & 19.83 & 0.90 & -3.51 & 23.74 & -58.28 & 89.06 \\
\hline (A3) & (1c) & 124.5 & 118.5 & 0.86 & 0.290 & 25.23 & 0.92 & -1.35 & 26.00 & -47.57 & 92.46 \\
\hline (A4) & (1d) & 113.6 & 118.5 & 0.93 & 0.201 & 13.77 & 0.95 & -2.81 & 16.27 & -44.51 & 39.25 \\
\hline (A5) & (1e) & 114.3 & 118.5 & 0.94 & 0.195 & 13.05 & 0.96 & -3.08 & 15.75 & -45.69 & 38.58 \\
\hline (A6) & (1f) & 117.3 & 118.5 & 0.93 & 0.178 & 13.22 & 0.96 & 0.01 & 14.19 & -25.59 & 34.85 \\
\hline (A7) & (1g) & 104.3 & 118.5 & 0.94 & 0.162 & 11.43 & 0.97 & 0.07 & 12.38 & -26.28 & 35.87 \\
\hline (A8) & (1h) & 112.1 & 118.5 & 0.44 & 0.557 & 22.88 & 0.53 & -4.83 & 45.40 & -138.2 & 121.0 \\
\hline (A9) & (1i) & 107.6 & 118.5 & 0.64 & 0.449 & 26.86 & 0.76 & -8.30 & 35.54 & -116.9 & 111.0 \\
\hline (A10) & $(1 \mathrm{j})$ & 113.3 & 118.5 & 0.75 & 0.356 & 24.04 & 0.85 & -2.30 & 28.07 & -69.04 & 43.45 \\
\hline (A11) & (1k) & 114.4 & 118.5 & 0.75 & 0.350 & 24.03 & 0.86 & -1.02 & 27.66 & -66.55 & 45.42 \\
\hline (A12) & (11) & 113.2 & 118.5 & 0.93 & 0.202 & 14.38 & 0.96 & -2.74 & 16.46 & -42.10 & 43.57 \\
\hline (A13) & $(1 \mathrm{~m})$ & 100.9 & 118.5 & 0.89 & 0.193 & 12.14 & 0.94 & 1.55 & 12.45 & -25.84 & 15.31 \\
\hline (A14) & $(1 \mathrm{n})$ & 98.24 & 118.5 & 0.91 & 0.172 & 11.62 & 0.95 & -0.79 & 11.30 & -16.27 & 19.06 \\
\hline (A15) & (10) & 113.2 & 118.5 & 0.93 & 0.202 & 14.38 & 0.96 & -2.72 & 16.47 & -42.13 & 43.60 \\
\hline (A16) & (1p) & 113.7 & 118.5 & 0.94 & 0.194 & 13.49 & 0.96 & -3.17 & 15.79 & -43.50 & 41.82 \\
\hline$(\mathrm{E} 1)$ & --- & 125.7 & 118.5 & 0.93 & 0.217 & 13.59 & 0.94 & 9.21 & 16.48 & -34.01 & 51.71 \\
\hline (E2) & --- & 123.0 & 118.5 & 0.93 & 0.227 & 12.50 & 0.93 & 6.40 & 18.24 & -46.33 & 51.57 \\
\hline (E3) & --- & 121.3 & 118.5 & 0.93 & 0.202 & 13.88 & 0.95 & 4.85 & 16.15 & -35.88 & 46.64 \\
\hline (E4) & --- & 119.0 & 118.5 & 0.46 & 0.552 & 21.73 & 0.54 & 2.32 & 45.75 & -129.2 & 126.1 \\
\hline (E5) & --- & 117.1 & 118.5 & 0.90 & 0.242 & 16.41 & 0.94 & 1.49 & 19.91 & -48.20 & 72.09 \\
\hline (E6) & --- & 114.3 & 118.5 & 0.70 & 0.440 & 18.18 & 0.70 & -1.81 & 37.49 & -122.6 & 95.44 \\
\hline (E7) & --- & 108.5 & 118.5 & 0.51 & 0.426 & 19.07 & 0.65 & 7.68 & 26.72 & -31.55 & 60.32 \\
\hline (E8) & --- & 117.5 & 118.5 & 0.90 & 0.248 & 15.93 & 0.93 & -2.43 & 20.13 & -55.53 & 49.93 \\
\hline (E9) & --- & 110.9 & 118.5 & 0.93 & 0.214 & 12.57 & 0.91 & 9.21 & 12.78 & -13.48 & 37.93 \\
\hline \multicolumn{12}{|c|}{ Urine nitrogen output $(\mathrm{g} / \mathrm{d})$} \\
\hline (B1) & $(2 a)$ & 69.54 & 64.62 & 0.48 & 0.702 & 18.73 & 0.61 & 2.79 & 30.34 & -102.3 & 64.18 \\
\hline (B2) & $(2 b)$ & 66.62 & 64.62 & 0.75 & 0.480 & 16.99 & 0.85 & 0.69 & 20.88 & -62.95 & 85.09 \\
\hline (B3) & $(2 c)$ & 68.18 & 64.62 & 0.77 & 0.459 & 18.29 & 0.87 & 1.47 & 20.49 & -46.73 & 74.17 \\
\hline (B4) & $(2 d)$ & 74.93 & 64.62 & 0.82 & 0.443 & 22.84 & 0.90 & 2.57 & 22.58 & -24.57 & 81.15 \\
\hline (B5) & $(2 \mathrm{e})$ & 67.35 & 64.62 & 0.86 & 0.348 & 14.72 & 0.93 & 1.23 & 15.57 & -54.28 & 54.31 \\
\hline (B6) & $(2 f)$ & 62.59 & 64.62 & 0.89 & 0.304 & 11.91 & 0.94 & 1.37 & 13.11 & -30.03 & 43.26 \\
\hline (B7) & $(2 \mathrm{~g})$ & & 64.62 & 0.89 & 0.296 & & 0.94 & 0.38 & & -28.74 & 45.16 \\
\hline (B8) & $(2 \mathrm{~h})$ & 67.88 & 64.62 & 0.42 & 0.741 & 14.54 & 0.48 & 2.90 & 33.36 & -101.3 & 54.52 \\
\hline (B9) & $(2 \mathrm{i})$ & 64.61 & 64.62 & 0.69 & 0.542 & 18.21 & 0.80 & 0.08 & 23.70 & -95.58 & 55.46 \\
\hline (B10) & $(2 \mathrm{j})$ & 65.64 & 64.62 & 0.80 & 0.429 & 17.40 & 0.89 & 0.48 & 19.36 & -37.28 & 56.73 \\
\hline (B11) & $(2 k)$ & & & 0.95 & & & & & & -4.89 & 20.19 \\
\hline (B12) & (2l) & 66.66 & 64.62 & 0.36 & 0.764 & 18.39 & 0.51 & 2.59 & 33.34 & -112.5 & 89.82 \\
\hline (B13) & $(2 \mathrm{~m})$ & 66.36 & 64.62 & 0.87 & 0.345 & 13.60 & 0.93 & 0.66 & 15.24 & -63.91 & 47.42 \\
\hline (B14) & $(2 n)$ & 65.73 & 64.62 & 0.86 & 0.352 & 14.25 & 0.92 & 0.39 & 15.73 & -61.53 & 54.50 \\
\hline (E10) & --- & 77.96 & 64.62 & 0.87 & 0.393 & 13.46 & 0.88 & 11.9 & 15.31 & -46.36 & 61.88 \\
\hline (E11) & --- & 70.17 & 64.62 & 0.86 & 0.433 & 19.79 & 0.83 & 4.56 & 20.02 & -60.93 & 43.75 \\
\hline (E12) & --- & 66.45 & 64.62 & 0.86 & 0.359 & 13.54 & 0.92 & 0.45 & 15.78 & -57.46 & 50.20 \\
\hline (E13) & --- & 65.68 & 64.62 & 0.86 & 0.377 & 12.33 & 0.90 & -0.19 & 16.62 & -60.54 & 46.15 \\
\hline (E14) & --- & 59.85 & 64.62 & 0.36 & 0.764 & 17.05 & 0.48 & -4.27 & 33.49 & -119.9 & 76.94 \\
\hline (E15) & --- & 61.16 & 64.62 & 0.36 & 0.763 & 17.43 & 0.49 & -2.95 & 33.44 & -118.4 & 79.96 \\
\hline (E16) & --- & 66.62 & 64.62 & 0.87 & 0.363 & 12.56 & 0.91 & 1.10 & 15.93 & -67.46 & 43.65 \\
\hline (E17) & --- & 57.90 & 64.62 & 0.83 & 0.426 & 13.83 & 0.87 & -6.87 & 18.35 & -75.83 & 46.52 \\
\hline
\end{tabular}


Faeces nitrogen output $(\mathrm{g} / \mathrm{d})$

\begin{tabular}{|c|c|c|c|c|c|c|c|c|c|c|c|}
\hline (C1) & (3a) & 46.97 & 47.86 & 0.56 & 0.338 & 8.425 & 0.72 & -1.921 & 10.74 & -36.67 & 40.50 \\
\hline (C2) & (3b) & 46.78 & 47.86 & 0.61 & 0.316 & 8.284 & 0.76 & -2.169 & 10.05 & -29.74 & 38.62 \\
\hline (C3) & $(3 c)$ & 49.12 & 47.86 & 0.75 & 0.259 & 6.178 & 0.83 & -1.021 & 8.393 & -27.34 & 20.20 \\
\hline (C4) & (3d) & 49.97 & 47.86 & 0.72 & 0.268 & 7.206 & 0.83 & -1.866 & 8.517 & -27.27 & 21.82 \\
\hline (C5) & $(3 e)$ & 49.93 & 47.86 & 0.79 & 0.271 & 8.080 & 0.86 & -3.549 & 9.408 & -21.82 & 16.48 \\
\hline (C6) & $(3 f)$ & 57.16 & 47.86 & 0.89 & 0.177 & 4.955 & 0.88 & 0.566 & 5.459 & -6.350 & 6.560 \\
\hline (C7) & $(3 g)$ & 45.32 & 47.86 & 0.85 & 0.201 & 6.123 & 0.91 & -2.144 & 6.607 & -20.82 & 16.03 \\
\hline (C8) & (3h) & 47.35 & 47.86 & 0.71 & 0.269 & 7.510 & 0.82 & -2.091 & 8.575 & -18.83 & 22.42 \\
\hline (C9) & (3i) & 46.37 & 47.86 & 0.60 & 0.328 & 6.290 & 0.68 & -2.143 & 10.55 & -26.97 & 25.46 \\
\hline (C10) & $(3 \mathrm{j})$ & 46.70 & 47.86 & 0.67 & 0.301 & 5.661 & 0.72 & -1.838 & 9.830 & -24.80 & 22.99 \\
\hline (C11) & $(3 k)$ & 47.74 & 47.86 & 0.76 & 0.261 & 5.839 & 0.81 & -2.801 & 8.261 & -22.92 & 13.56 \\
\hline (C12) & (31) & 46.59 & 47.86 & 0.65 & 0.304 & 7.602 & 0.77 & -2.182 & 9.614 & -22.92 & 32.08 \\
\hline (C13) & $(3 m)$ & 49.72 & 47.86 & 0.77 & 0.245 & 6.148 & 0.85 & -2.007 & 7.728 & -20.43 & 18.73 \\
\hline (C14) & $(3 n)$ & 46.06 & 47.86 & 0.77 & 0.262 & 5.451 & 0.81 & -1.445 & 8.765 & -21.10 & 17.91 \\
\hline (C15) & (3o) & 48.15 & 47.86 & 0.68 & 0.293 & 5.396 & 0.72 & -1.407 & 9.600 & -22.02 & 21.85 \\
\hline (C16) & $(3 p)$ & 45.81 & 47.86 & 0.35 & 0.409 & 7.030 & 0.48 & -2.431 & 13.28 & -45.98 & 25.64 \\
\hline (C17) & (3q) & 45.56 & 47.86 & 0.40 & 0.397 & 8.001 & 0.56 & -2.805 & 12.71 & -37.53 & 25.10 \\
\hline (C18) & $(3 r)$ & 46.16 & 47.86 & 0.10 & 0.458 & 3.246 & 0.13 & -1.771 & 15.42 & -40.68 & 34.48 \\
\hline (E18) & --- & 53.36 & 47.86 & 0.55 & 0.359 & 12.24 & 0.72 & 3.961 & 12.46 & -25.71 & 57.45 \\
\hline (E19) & --- & 55.59 & 47.86 & 0.60 & 0.393 & 14.50 & 0.70 & 6.215 & 14.49 & -21.52 & 43.93 \\
\hline (E20) & --- & 48.38 & 47.86 & 0.60 & 0.325 & 6.343 & 0.69 & -0.145 & 10.53 & -24.89 & 27.53 \\
\hline (E21) & --- & 47.12 & 47.86 & 0.60 & 0.320 & 8.238 & 0.75 & -1.604 & 10.23 & -23.42 & 28.40 \\
\hline (E22) & --- & 46.95 & 47.86 & 0.10 & 0.458 & 4.171 & 0.16 & -1.002 & 15.34 & -37.76 & 36.04 \\
\hline (E23) & --- & 44.60 & 47.86 & 0.10 & 0.473 & 6.481 & 0.21 & -3.401 & 15.43 & -40.28 & 35.63 \\
\hline
\end{tabular}

Eq. = equation; $\mathrm{r}^{2}=$ correlation between predicted and actual values; $\mathrm{MPE}=$ mean prediction error; $\mathrm{SE}=$ standard error; Rc = Lin's concordance correlation coefficient; SD = standard deviation; Min = minimum value observed; Max = maximum value observed.

${ }^{a}$ Equations are presented in Table A1 (Eq. A1-A16, B1-B14, C1-C18) and Table A3 (Eq. E1-E23). 
Table 5 Internal validation using one-third of the whole data-set $(n=97)$ and equations developed from the remaining two-thirds of the whole data-set $(n=192)$

\begin{tabular}{|c|c|c|c|c|c|c|c|c|c|c|c|}
\hline \multirow[b]{2}{*}{ Eq. $^{\text {a }}$} & \multirow[b]{2}{*}{ Original Eq. } & \multirow[b]{2}{*}{ Predicted } & \multirow[b]{2}{*}{ Actual } & \multirow[b]{2}{*}{$\mathrm{r}^{2}$} & \multirow[b]{2}{*}{ MPE } & \multirow[b]{2}{*}{ SE } & \multirow[b]{2}{*}{ Rc } & \multicolumn{4}{|c|}{ Predicted - Actual } \\
\hline & & & & & & & & Mean & $\mathrm{SD}$ & Min & Max \\
\hline \multicolumn{12}{|c|}{ Urine nitrogen : Nitrogen intake } \\
\hline (D1) & (4a) & 0.408 & 0.396 & 0.19 & 0.367 & 0.031 & 0.24 & 0.009 & 0.101 & -0.272 & 0.217 \\
\hline (D2) & (4b) & 0.403 & 0.396 & 0.32 & 0.343 & 0.050 & 0.48 & 0.006 & 0.092 & -0.305 & 0.23 \\
\hline (D3) & $(4 c)$ & 0.386 & 0.396 & 0.46 & 0.311 & 0.052 & 0.60 & -0.005 & 0.082 & -0.225 & 0.19 \\
\hline (D4) & $(4 d)$ & 0.387 & 0.396 & 0.50 & 0.300 & 0.047 & 0.61 & -0.004 & 0.079 & -0.217 & 0.188 \\
\hline (D5) & $(4 \mathrm{e})$ & 0.408 & 0.396 & 0.35 & 0.338 & 0.054 & 0.52 & 0.009 & 0.090 & -0.284 & 0.236 \\
\hline (D6) & (4f) & 0.403 & 0.396 & 0.34 & 0.337 & 0.049 & 0.49 & 0.006 & 0.0 & -0.319 & 0.21 \\
\hline (D7) & $(4 g)$ & 0.389 & 0.396 & 0.34 & 0.325 & 0.049 & 0.51 & 0.017 & 0.082 & -0.238 & 0.22 \\
\hline (D8) & (4h) & 0.398 & 0.396 & 0.37 & 0.323 & 0.053 & 0.55 & 0.014 & 0.084 & -0.263 & 0.20 \\
\hline (D9) & (4i) & 0.389 & 0.396 & 0.38 & 0.320 & 0.061 & 0.60 & 0.011 & 0.0 & -0.260 & 0.23 \\
\hline (D10) & $(4 \mathrm{j})$ & 0.392 & 0.396 & 0.39 & 0.320 & 0.063 & 0.61 & 0.006 & 0.084 & -0.267 & 0.21 \\
\hline (D11) & $(4 \mathrm{k})$ & 0.401 & 0.396 & 0.40 & 0.329 & 0.050 & 0.54 & 0.005 & 0.089 & -0.334 & 0.24 \\
\hline (D12) & & 0.396 & 0.396 & 0.51 & 0.301 & 0.049 & 0.63 & 0.001 & 0.083 & -0.197 & 0.22 \\
\hline (D13) & $(4 \mathrm{~m})$ & 0.382 & 0.396 & 0.46 & 0.313 & 0.055 & 0.62 & -0.008 & 0.083 & -0.225 & 0.19 \\
\hline (D14) & $(4 n)$ & 0.397 & 0.396 & 0.18 & 0.370 & 0.043 & 0.31 & 0.002 & 0.101 & -0.367 & 0.21 \\
\hline (D15) & (4o) & 0.386 & 0.396 & 0.37 & 0.333 & 0.047 & 0.50 & -0.006 & 0.088 & -0.230 & 0.18 \\
\hline
\end{tabular}

Retained nitrogen : Nitrogen intake

$\begin{array}{llllllll}\text { (F1) } & \text { (5a) } & 0.275 & 0.264 & 0.15 & 0.470 & 0.020 & 0.17 \\ \text { (F2) } & \text { (5b) } & 0.273 & 0.264 & 0.21 & 0.458 & 0.026 & 0.24 \\ \text { (F3) } & \text { (5c) } & 0.279 & 0.264 & 0.16 & 0.456 & 0.026 & 0.24 \\ \text { (F4) } & \text { (5d) } & 0.262 & 0.264 & 0.19 & 0.464 & 0.035 & 0.34 \\ \text { (F5) } & \text { (5e) } & 0.277 & 0.264 & 0.19 & 0.459 & 0.035 & 0.29 \\ \text { (F6) } & (5 f) & 0.276 & 0.264 & 0.19 & 0.469 & 0.030 & 0.26 \\ (\text { F7 }) & \text { (5g) } & 0.280 & 0.264 & 0.18 & 0.457 & 0.027 & 0.25 \\ \text { (F8) } & \text { (5h) } & 0.490 & 0.264 & 0.02 & 0.490 & 0.021 & 0.06\end{array}$

$\begin{array}{llll}0.011 & 0.087 & -0.189 & 0.238 \\ 0.010 & 0.084 & -0.187 & 0.215 \\ 0.006 & 0.081 & -0.192 & 0.219 \\ 0.001 & 0.081 & -0.182 & 0.191 \\ 0.008 & 0.081 & -0.171 & 0.200 \\ 0.014 & 0.086 & -0.200 & 0.205 \\ 0.008 & 0.082 & -0.200 & 0.218 \\ 0.006 & 0.088 & -0.187 & 0.224\end{array}$

Urine nitrogen : Manure nitrogen

\begin{tabular}{llllllllllll} 
(G1) & (6a) & 0.556 & 0.537 & 0.14 & 0.287 & 0.035 & 0.22 & 0.016 & 0.106 & -0.223 & 0.276 \\
(G2) & $(6 \mathrm{~b})$ & 0.549 & 0.537 & 0.39 & 0.249 & 0.060 & 0.58 & 0.011 & 0.089 & -0.271 & 0.237 \\
(G3) & $(6 \mathrm{c})$ & 0.549 & 0.537 & 0.48 & 0.239 & 0.065 & 0.66 & 0.014 & 0.087 & -0.155 & 0.212 \\
(G4) & $(6 \mathrm{f})$ & 0.530 & 0.537 & 0.77 & 0.150 & 0.047 & 0.87 & -0.001 & 0.054 & -0.138 & 0.159 \\
(G5) & $(6 \mathrm{~g})$ & 0.556 & 0.537 & 0.37 & 0.256 & 0.066 & 0.57 & 0.016 & 0.091 & -0.229 & 0.246 \\
(G6) & $(6 \mathrm{i})$ & 0.528 & 0.537 & 0.56 & 0.216 & 0.074 & 0.72 & 0.012 & 0.081 & -0.248 & 0.223 \\
(G7) & $(6 \mathrm{j})$ & 0.552 & 0.537 & 0.24 & 0.275 & 0.031 & 0.27 & 0.017 & 0.104 & -0.260 & 0.245 \\
(G8) & $(6 \mathrm{k})$ & 0.551 & 0.537 & 0.30 & 0.244 & 0.041 & 0.38 & 0.016 & 0.099 & -0.229 & 0.259 \\
(G9) & $(61)$ & 0.543 & 0.537 & 0.48 & 0.267 & 0.057 & 0.64 & 0.009 & 0.084 & -0.304 & 0.214 \\
(G10) & $(6 \mathrm{~m})$ & 0.549 & 0.537 & 0.61 & 0.212 & 0.063 & 0.75 & 0.021 & 0.078 & -0.131 & 0.234 \\
(G11) & $(6 \mathrm{n})$ & 0.525 & 0.537 & 0.78 & 0.148 & 0.048 & 0.88 & -0.003 & 0.054 & -0.137 & 0.145 \\
(G12) & $(6 \mathrm{o})$ & 0.543 & 0.537 & 0.30 & 0.265 & 0.055 & 0.47 & 0.008 & 0.096 & -0.334 & 0.241 \\
(G13) & $(6 \mathrm{p})$ & 0.529 & 0.537 & 0.76 & 0.158 & 0.047 & 0.85 & -0.002 & 0.057 & -0.141 & 0.140 \\
(E24) & --- & 0.558 & 0.537 & 0.37 & 0.287 & 0.088 & 0.60 & 0.017 & 0.099 & -0.210 & 0.265 \\
(E25) & --- & 0.559 & 0.537 & 0.37 & 0.249 & 0.052 & 0.51 & 0.020 & 0.091 & -0.238 & 0.238 \\
(E26) & --- & 0.538 & 0.537 & 0.30 & 0.238 & 0.048 & 0.47 & 0.002 & 0.096 & -0.339 & 0.232 \\
(E27) & --- & 0.550 & 0.537 & 0.30 & 0.235 & 0.052 & 0.43 & 0.014 & 0.096 & -0.323 & 0.218 \\
(E28) & --- & 0.503 & 0.537 & 0.76 & 0.238 & 0.040 & 0.78 & -0.029 & 0.060 & -0.153 & 0.118 \\
\hline
\end{tabular}

Eq. = equation; $\mathrm{r}^{2}=$ correlation between predicted and actual values; MPE = mean prediction error; $\mathrm{SE}=$ standard error; Rc = Lin's concordance correlation coefficient; SD = standard deviation; Min = minimum value observed; Max = maximum value observed .

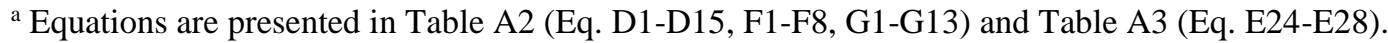




\section{Figures}
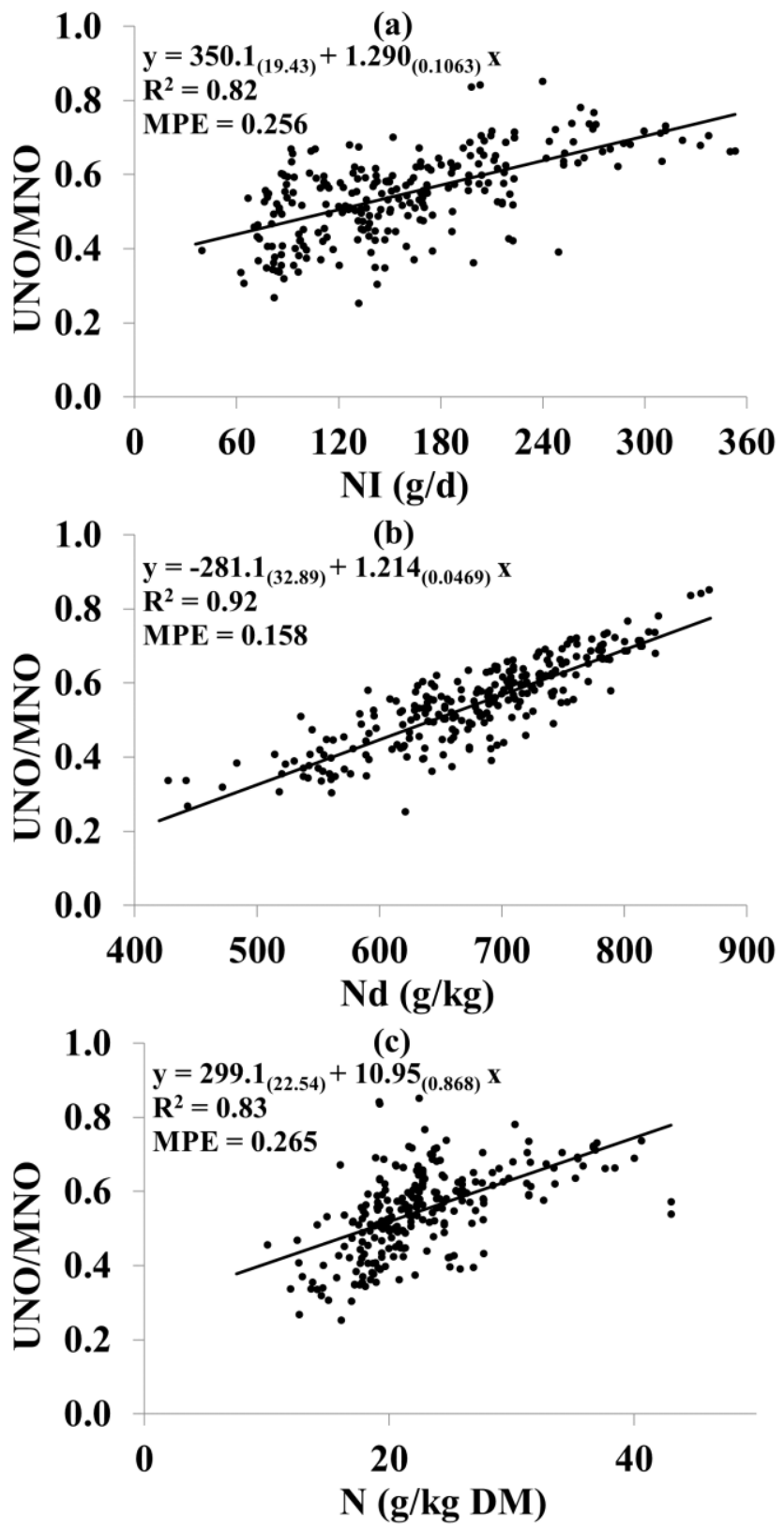

Fig. 1 

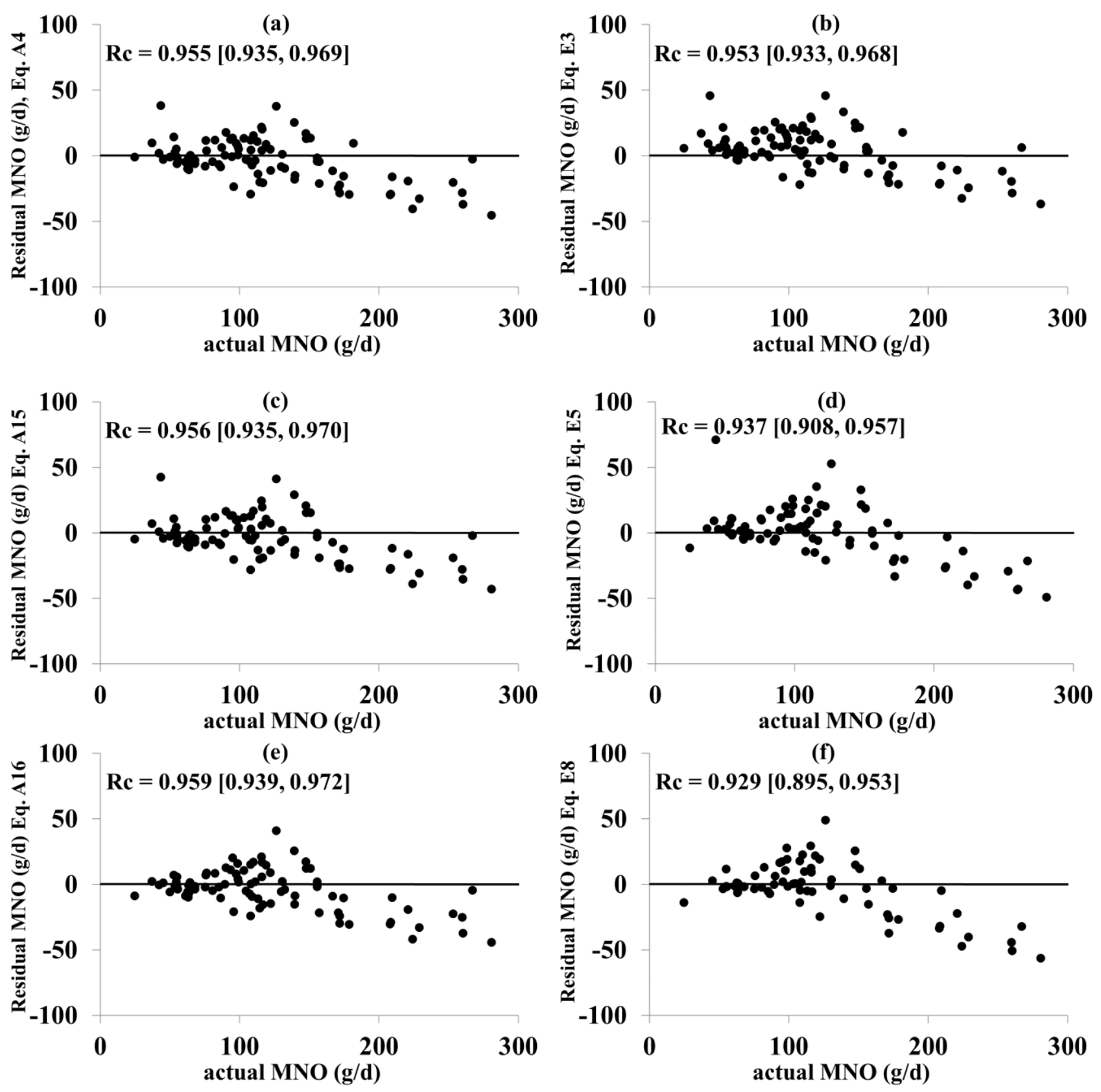

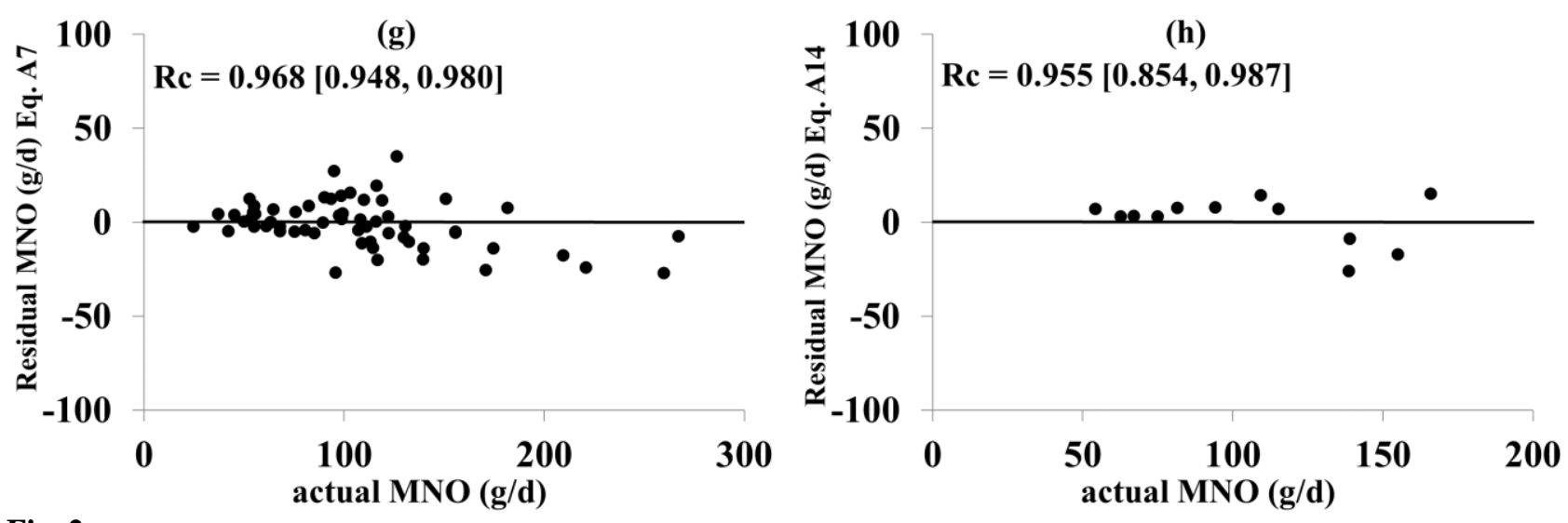

Fig. 2
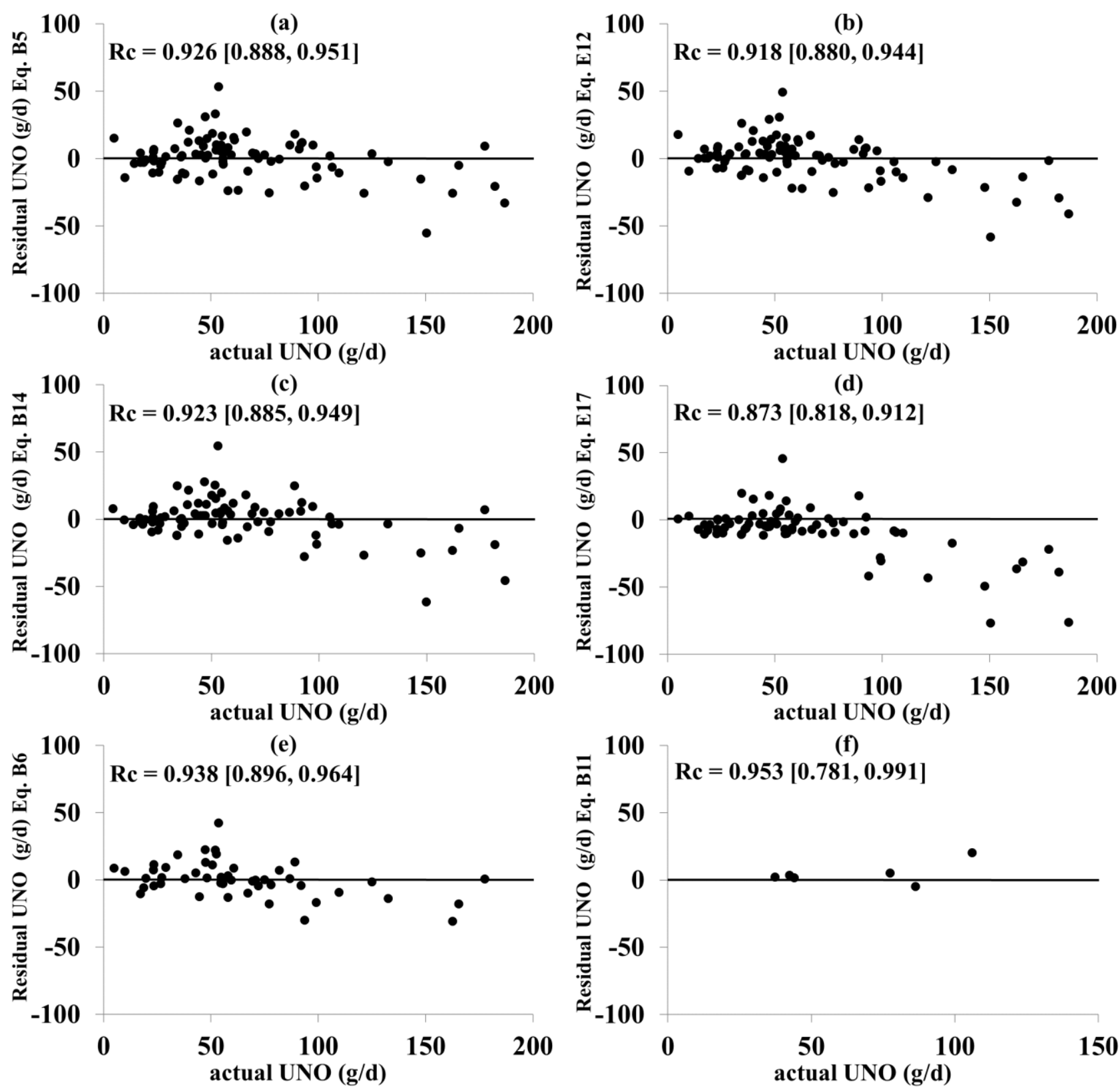

Fig. 3 

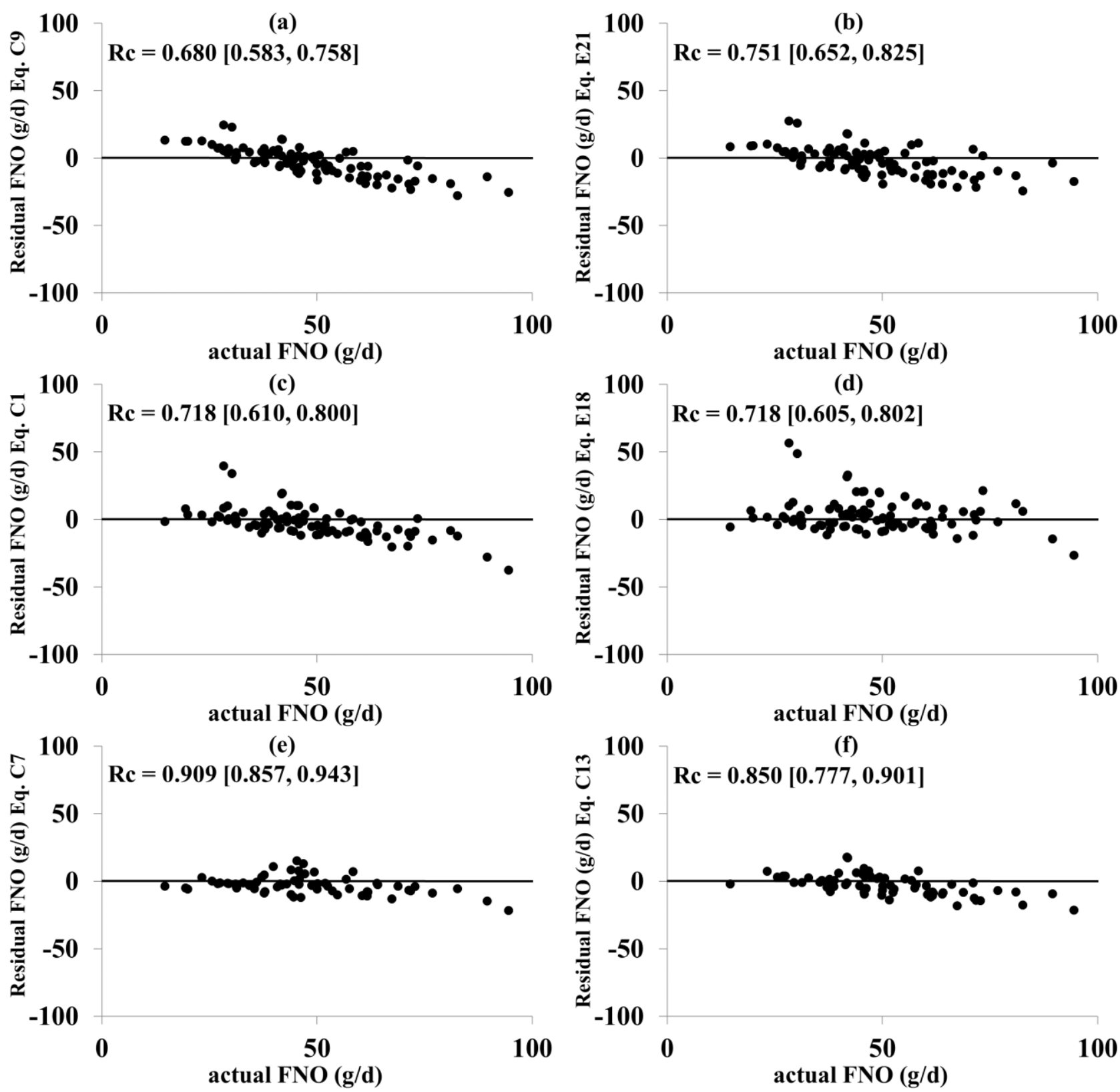

Fig. 4 


\section{APPENDIX}

Table A1 Internal validation: Single and multiple linear prediction of manure nitrogen output, urine nitrogen output and faeces nitrogen output, using intakes of feed, nutrient and energy, total forage proportion, body weight, apparent total tract digestibility, diet chemical composition, and two-thirds of the whole database $(n=192)$

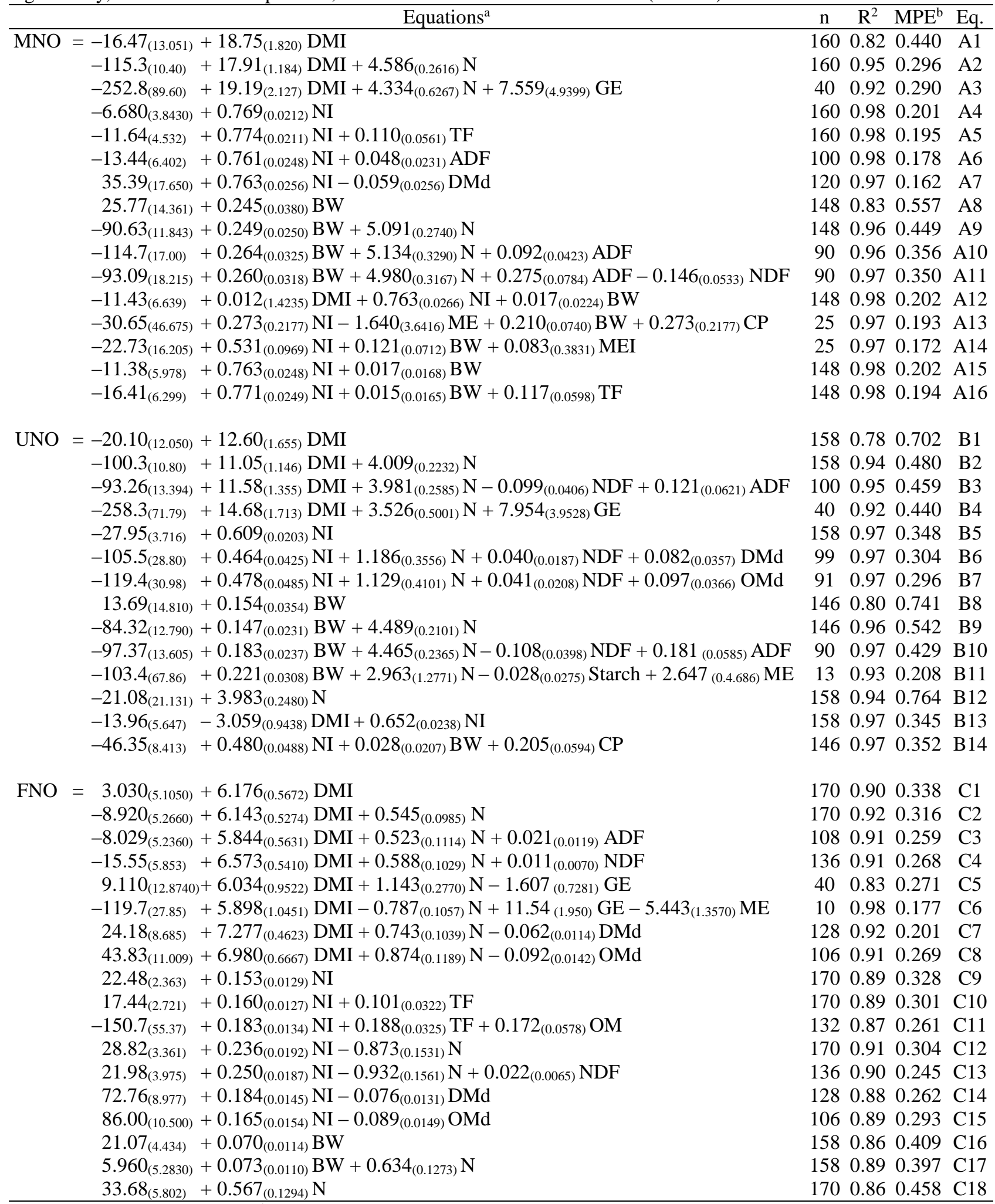

$\mathrm{n}=$ number of observations; $\mathrm{R}^{2}=$ pseudo correlation coefficient; $\mathrm{MPE}=$ mean prediction error; Eq. = equation; $\mathrm{MNO}=$ 
manure nitrogen output; DMI = dry matter intake; $\mathrm{N}=$ diet nitrogen content; $\mathrm{GE}=$ diet gross energy content; $\mathrm{NI}=$ nitrogen intake; $\mathrm{TF}=$ diet forage proportion; $\mathrm{ADF}=$ diet acid-detergent fibre content; $\mathrm{DMd}=$ dry matter apparent digestibility; $\mathrm{BW}=$ body weight; NDF = diet neutral-detergent fibre content; $\mathrm{CP}=$ diet crude protein content; $\mathrm{MEI}=$ metabolisable energy intake; $\mathrm{UNO}=$ urine nitrogen output; OMd = organic matter apparent digestibility; $\mathrm{ME}=$ diet metabolisable energy content; $\mathrm{FNO}=$ faeces nitrogen output; $\mathrm{OM}=$ diet organic matter content.

${ }^{a}{ }^{\text {Units: }}$ /d for MNO, UNO, FNO; kg/d for DMI; g/kg DM for N, NDF, ADF, CP, Starch, OM; MJ/kg DM for GE, ME; $\mathrm{g} / \mathrm{d}$ for NI; g/100g DM for TF; $\mathrm{g} / \mathrm{kg}$ for DMd, OMd; MJ/d for MEI. The effect of all explanatory variables was significant according to the Wald statistic (Fpr < 0.05), except from the variables used in equations A14 to A16, B13 and B14, which were developed to include the same predictors as external equations.

${ }^{b}$ MPE derived from an internal validation against the remaining one-third of the whole database. 
Table A2 Internal validation: Single and multiple linear prediction of urine nitrogen output and retained nitrogen expressed per nitrogen intake and urine nitrogen output expressed per manure nitrogen output, using intakes of feed, nutrient and energy, total forage proportion, body weight, apparent total tract digestibility, diet chemical composition, and two-thirds of the whole database $(\mathrm{n}=192)$.

\begin{tabular}{|c|c|c|c|c|c|c|}
\hline & & Equations $^{\mathrm{a}}$ & $\mathrm{n}$ & $\mathrm{R}^{2}$ & $\mathrm{MPE}^{\mathrm{b}}$ & Eq. \\
\hline $\begin{array}{l}\mathrm{UNO} / \mathrm{NI} \\
\left(\times 10^{3}\right)\end{array}$ & $\begin{aligned}= & 289.3_{(38.96)} \\
& 103.6_{(41.77)} \\
- & 177.7_{(60.45)} \\
- & 222.7_{(64.82)} \\
& 244.6_{(22.71)} \\
& 202.4_{(26.51)} \\
& 41.09_{(104.075)} \\
- & 360.5_{(172.71)} \\
- & 116.8_{(117.39)} \\
- & 402.7_{(181.04)} \\
& 101.2_{(40.28)} \\
- & 178.3_{(61.12)} \\
& 211.4_{(27.40)} \\
- & 106.3_{(55.52)}\end{aligned}$ & $\begin{array}{l}+16.71_{(5.462)} \mathrm{DMI} \\
+16.03_{(4.794)} \mathrm{DMI}+8.362_{(1.0471)} \mathrm{N} \\
+12.70_{(4.731)} \mathrm{DMI}+0.714_{(0.0791)} \mathrm{Nd} \\
+12.35_{(4.681)} \mathrm{DMI}+0.751_{(0.0812)} \mathrm{Nd}+0.603_{(0.3219)} \mathrm{TF} \\
+1.036_{(0.1265)} \mathrm{NI} \\
+0.658_{(0.1795)} \mathrm{NI}+4.373_{(1.5043)} \mathrm{N} \\
+0.849_{(0.1523)} \mathrm{NI}+0.322_{(0.1498)} \mathrm{DMd} \\
+0.773_{(0.1515)} \mathrm{NI}+0.768_{(0.2114)} \mathrm{DMd}+0.295_{(0.1112)} \mathrm{NDF} \\
+0.912_{(0.1398)} \mathrm{NI}+0.507_{(0.1657)} \mathrm{OMd} \\
+0.846_{(0.1412)} \mathrm{NI}+0.799_{(0.2143)} \mathrm{OMd}+0.252_{(0.1210)} \mathrm{NDF} \\
+0.271_{(0.8402)} \mathrm{BW}+9.37_{(1.1103)} \mathrm{N} \\
+0.228_{(0.0832)} \mathrm{BW}+0.727_{(0.0798)} \mathrm{Nd} \\
+8.371_{(1.0694)} \mathrm{N} \\
+0.740_{(0.0796)} \mathrm{Nd}\end{array}$ & $\begin{array}{l}158 \\
158 \\
153 \\
153 \\
158 \\
158 \\
121 \\
99 \\
97 \\
91 \\
146 \\
141 \\
158 \\
153\end{array}$ & $\begin{array}{l}0.81 \\
0.85 \\
0.89 \\
0.89 \\
0.86 \\
0.87 \\
0.84\end{array}$ & $\begin{array}{l}0.367 \\
0.343 \\
0.311 \\
0.300 \\
0.338 \\
0.337 \\
0.325 \\
0.323 \\
0.320 \\
0.320 \\
0.329 \\
0.313 \\
0.370 \\
0.333\end{array}$ & $\begin{array}{c}\text { D1 } \\
\text { D2 } \\
\text { D3 } \\
\text { D4 } \\
\text { D5 } \\
\text { D6 } \\
\text { D7 } \\
\text { D8 } \\
\text { D9 } \\
\text { D10 } \\
\text { D11 } \\
\text { D12 } \\
\text { D13 } \\
\text { D14 }\end{array}$ \\
\hline $\begin{array}{l}\text { RN/NI } \\
\left(\mathrm{x} 10^{3}\right)\end{array}$ & $\begin{aligned} & 346.3_{(35.69)} \\
& 377.5_{(36.90)} \\
& 177.4_{(60.70)} \\
& 223.5_{(72.30)} \\
& 242.3_{(75.66)} \\
& 384.0_{(36.10)} \\
& 179.4_{(61.44)} \\
& 105.7_{(55.57)}\end{aligned}$ & $\begin{array}{l}-9.972_{(4.8722)} \mathrm{DMI} \\
-10.03_{(4.744)} \mathrm{DMI}-0.829_{(0.3267)} \mathrm{TF} \\
-12.60_{(4.755)} \mathrm{DMI}+0.286_{(0.0793)} \mathrm{Nd} \\
-15.69_{(5.833)} \mathrm{DMI}+0.328_{(0.0849)} \mathrm{Nd}-0.337_{(0.1281)} \mathrm{ADF} \\
-11.14_{(5.092)} \mathrm{DMI}+0.273_{(0.0856)} \mathrm{Nd}-0.196_{(0.0762)} \mathrm{NDF} \\
-0.218_{(0.0860)} \mathrm{BW}-0.794_{(0.3435)} \mathrm{TF} \\
-0.230_{(0.0838)} \mathrm{BW}+0.273_{(0.0800)} \mathrm{Nd} \\
+0.261_{(0.0797)} \mathrm{Nd}\end{array}$ & $\begin{array}{c}157 \\
157 \\
151 \\
94 \\
122 \\
145 \\
139 \\
151\end{array}$ & $\begin{array}{l}0.83 \\
0.83 \\
0.82 \\
0.86 \\
0.84\end{array}$ & $\begin{array}{l}0.470 \\
0.458 \\
0.456 \\
0.464 \\
0.459 \\
0.469 \\
0.457 \\
0.490\end{array}$ & $\begin{array}{l}\text { F1 } \\
\text { F2 } \\
\text { F3 } \\
\text { F4 } \\
\text { F5 } \\
\text { F6 } \\
\text { F7 } \\
\text { F8 }\end{array}$ \\
\hline $\begin{array}{l}\mathrm{UNO} / \mathrm{MNO}= \\
\left(\mathrm{x} 10^{3}\right)\end{array}$ & $\begin{aligned} & 425.7_{(39.36)} \\
& 179.5_{(39.51)} \\
& 250.5_{(57.71)} \\
- & 300.2_{(41.80)} \\
& 354.4_{(22.22)} \\
- & 255.1_{(106.65)} \\
& 450.5_{(35.63)} \\
& 501.3_{(37.39)} \\
& 172.4_{(37.73)} \\
& 244.5_{(63.77)} \\
- & 298.9_{(41.74)} \\
& 289.7_{(27.09)} \\
- & 262.1_{(38.97)}\end{aligned}$ & $\begin{array}{l}+18.28_{(5.524)} \mathrm{DMI} \\
+16.50_{(4.435)} \mathrm{DMI}+11.35_{(1.060)} \mathrm{N} \\
+16.14_{(5.658)} \mathrm{DMI}+11.00_{(1.153)} \mathrm{N}-0.364_{(0.1683)} \mathrm{NDF}+0.288_{(0.2548)} \mathrm{ADF} \\
+7.158_{(3.1728)} \mathrm{DMI}+1.173_{(0.0560)} \mathrm{Nd} \\
+1.278_{(0.1270)} \mathrm{NI} \\
+1.185_{(0.1415)} \mathrm{NI}+0.834_{(0.1504)} \mathrm{OMd} \\
+0.286_{(0.0962)} \mathrm{BW} \\
+0.269_{(0.0898)} \mathrm{BW}-1.139_{(0.3624)} \mathrm{TF} \\
+0.275_{(0.0753)} \mathrm{BW}+12.53_{(1.120)} \mathrm{N} \\
+0.283_{(0.0959)} \mathrm{BW}+12.56_{(1.219)} \mathrm{N}-0.422_{(0.1701)} \mathrm{NDF}+0.337_{(0.2360)} \mathrm{ADF} \\
+0.136_{(0.0534)} \mathrm{BW}+1.173_{(0.0563)} \mathrm{Nd} \\
+11.42_{(1.085)} \mathrm{N} \\
+1.190_{(0.056))} \mathrm{Nd}\end{array}$ & $\begin{array}{r}157 \\
157 \\
100 \\
153 \\
157 \\
96 \\
145 \\
145 \\
145 \\
90 \\
141 \\
157 \\
153\end{array}$ & $\begin{array}{l}0.83 \\
0.86 \\
0.93 \\
0.82 \\
0.88 \\
0.69 \\
0.67 \\
0.84 \\
0.87 \\
0.93 \\
0.83 \\
0.92\end{array}$ & $\begin{array}{l}0.287 \\
0.249 \\
0.239 \\
0.150 \\
0.256 \\
0.216 \\
0.275 \\
0.244 \\
0.267 \\
0.212 \\
0.148 \\
0.265 \\
0.158\end{array}$ & $\begin{array}{c}\text { G1 } \\
\text { G2 } \\
\text { G3 } \\
\text { G4 } \\
\text { G5 } \\
\text { G6 } \\
\text { G7 } \\
\text { G8 } \\
\text { G9 } \\
\text { G10 } \\
\text { G11 } \\
\text { G12 } \\
\text { G13 }\end{array}$ \\
\hline
\end{tabular}

$\mathrm{n}=$ number of observations; $\mathrm{R}^{2}=$ pseudo correlation coefficient; $\mathrm{MPE}=$ mean prediction error; Eq. = equation; $\mathrm{UNO}=$ urine nitrogen output; $\mathrm{NI}=$ nitrogen intake; $\mathrm{DMI}=$ dry matter intake; $\mathrm{N}=$ diet nitrogen content; $\mathrm{Nd}=$ nitrogen apparent digestibility; $\mathrm{TF}=$ diet forage proportion; $\mathrm{DMd}=$ dry matter apparent digestibility; $\mathrm{NDF}=$ diet neutral detergent fibre content; $\mathrm{OMd}=$ organic matter apparent digestibility; BW = body weight; RN = retained nitrogen; $\mathrm{ADF}=$ diet acid-detergent fibre content; $\mathrm{MNO}=$ manure nitrogen output.

a Units: g/g for UNO/NI, RN/NI, UNO/MNO; kg/d for DMI; g/kg DM for N, NDF, ADF; g/kg for Nd, DMd, OMd; g/100g $\mathrm{DM}$ for TF; $\mathrm{g} / \mathrm{d}$ for NI; $\mathrm{kg}$ for BW. The effect of all explanatory variables was significant according to the Wald statistic (Fpr $<0.05)$. The random effects of the individual experiment and animal breed were accounted for all predicted variables, according to changes in deviance during the development of the random model.

${ }^{b}$ MPE derived from an internal validation against the remaining one-third of the whole database. 
Table A3 Internal validation: Prediction of manure, urine, faeces nitrogen output and urine nitrogen output expressed per manure nitrogen output, as presented by other authors.

\begin{tabular}{|c|c|c|}
\hline & Equations $^{\mathrm{a}}$ & MPE $^{\mathrm{b}}$ Eq. $^{\mathrm{c}}$ \\
\hline \multirow[t]{9}{*}{$\overline{\mathrm{MNO}}$} & $=6.91+0.759 \mathrm{NI}$ & $0.217 \quad(\mathrm{E} 1)$ \\
\hline & $13.8+0.698 \mathrm{NI}$ & $0.227 \quad(\mathrm{E} 2)$ \\
\hline & $0.775 \mathrm{NI}$ & 0.202 (E3) \\
\hline & $8.6+1.385 \mathrm{MBW}$ & $0.552(\mathrm{E} 4)$ \\
\hline & $-24.7+0.609 \mathrm{NI}+0.599 \mathrm{MBW}$ & 0.242 (E5) \\
\hline & $15+(0.55+0.032 \mathrm{NI} / \mathrm{DMI}) \mathrm{MBW}$ & $0.440 \quad(\mathrm{E} 6)$ \\
\hline & $26.4+(0.071+0.523 \mathrm{NI} / \mathrm{MEI}) \mathrm{MBW}$ & 0.426 (E7) \\
\hline & $-25.8+0.595 \mathrm{MBW}+(0.579+0.058 \mathrm{FP}) \mathrm{NI}$ & $0.248(\mathrm{E} 8)$ \\
\hline & $11.50+0.65 \mathrm{NI}-4.47 \mathrm{ME}+1.77 \mathrm{CP}+0.432 \mathrm{MBW}$ & 0.214 (E9) \\
\hline \multirow[t]{8}{*}{ UNO } & $=0.23 \mathrm{NI}^{1.15}$ & $0.393(\mathrm{E} 10)$ \\
\hline & $6.8+0.405 \mathrm{NI}$ & $0.433(\mathrm{E} 11)$ \\
\hline & $-21.18+0.56 \mathrm{NI}$ & $0.359(\mathrm{E} 12)$ \\
\hline & $-14.12+0.51 \mathrm{NI}$ & $0.377(\mathrm{E} 13)$ \\
\hline & $-21.52+5.91 \mathrm{CP}$ & $0.764(\mathrm{E} 14)$ \\
\hline & $-22+6.04 \mathrm{CP}$ & $0.763(\mathrm{E} 15)$ \\
\hline & $-3.93+0.62 \mathrm{NI}-3.72 \mathrm{DMI}$ & $0.363(\mathrm{E} 16)$ \\
\hline & $-71.2+0.265 \mathrm{NI}+3.76 \mathrm{CP}+0.468 \mathrm{MBW}$ & 0.426 (E17) \\
\hline \multirow[t]{6}{*}{ FNO } & $=4.91 \mathrm{DMI}^{1.21}$ & $0.359(\mathrm{E} 18)$ \\
\hline & $0.506+0.352 \mathrm{NI}$ & 0.393 (E19) \\
\hline & $24.28+0.154 \mathrm{NI}$ & $0.325(\mathrm{E} 20)$ \\
\hline & $15.82+0.2 \mathrm{NI}$ & $0.320(\mathrm{E} 21)$ \\
\hline & $30.91+1.165 \mathrm{CP}$ & 0.458 (E22) \\
\hline & $19.68+1.81 \mathrm{CP}$ & $0.473(\mathrm{E} 23)$ \\
\hline \multirow[t]{5}{*}{$\mathrm{UNO} /$} & $=0.29+0.0017 \mathrm{NI}$ & 0.265 (E24) \\
\hline & $0.402+0.001 \mathrm{NI}$ & $0.253(\mathrm{E} 25)$ \\
\hline & $0.288+0.018 \mathrm{CP}$ & 0.264 (E26) \\
\hline & $0.328+0.016 \mathrm{CP}$ & 0.264 (E27) \\
\hline & $-0.162+0.01 \mathrm{Nd}$ & $0.175(\mathrm{E} 28)$ \\
\hline
\end{tabular}

$\mathrm{MPE}=$ mean prediction error; Eq. = equation; $\mathrm{MNO}=$ manure nitrogen output; $\mathrm{NI}=$ nitrogen intake; $\mathrm{MBW}=$ metabolic body weight $\left(\right.$ body weight $\left.{ }^{0.75}\right) ; \mathrm{DMI}=$ dry matter intake; $\mathrm{MEI}=$ metabolisable energy intake; $\mathrm{FP}=$ diet forage proportion; $\mathrm{ME}=$ metabolisable energy; $\mathrm{CP}=$ diet crude protein content; $\mathrm{Nd}=$ nitrogen apparent digestibility.

${ }^{a}$ Units: g/d for NI; $\mathrm{kg}$ for MBW; $\mathrm{kg} / \mathrm{d}$ for DMI; MJ/d for MEI; $\mathrm{kg} / \mathrm{kg}$ DM for FP; MJ/kg $\mathrm{DM}$ for ME; g/100g DM for CP; $\mathrm{g} / 100 \mathrm{~g}$ for $\mathrm{Nd}$.

${ }^{b}$ MPE derived from an internal validation against the same one-third of the whole dataset that was used to validate equations developed in the current study.

c References: E1, E9, E11, E17, E19, (Reed et al., 2015); E2 - E8, (Yan et al., 2007); E10, E18, (Hirooka, 2010); E12, E14, E16, E20, E22, E24, E26, (Waldrip et al., 2013); E13, E15, E21, E23, E25, E27, E28, (Dong et al., 2014). 


\section{List of studies used for the development of prediction models}

Archibeque, S.L., Burns, J.C., Huntington, G.B., 2001. Urea flux in beef steers: effects of forage species and nitrogen fertilization. J. Anim. Sci. 79, 1937-1943.

Archibeque, S.L., Burns, J.C., Huntington, G.B., 2002. Nitrogen metabolism of beef steers fed endophyte-free tall fescue hay: effects of ruminally protected methionine supplementation. J. Anim. Sci. 80, 1344-1351.

Archibeque, S.L., Freetly, H.C., Cole, N.A., Ferrell, C.L., 2007. The influence of oscillating dietary protein concentrations on finishing cattle. II. Nutrient retention and ammonia emissions. J. Anim. Sci. 85, 1496-1503.

Archibeque, S.L., Miller, D.N., Freetly, H.C., Ferrell, C.L., 2006. Feeding high-moisture corn instead of dry-rolled corn reduces odorous compound production in manure of finishing beef cattle without decreasing performance. J. Anim. Sci. 84, 1767-1777.

Arias, R.P., Unruh-Snyder, L.J., Scholljegerdes, E.J., Baird, A.N., Johnson, K.D., Buckmaster, D., Lemenager, R.P., Lake, S.L., 2012. Effects of feeding corn modified wet distillers grain plus solubles co-ensiled with direct-cut forage on feedlot performance, carcass characteristics, and diet digestibility of finishing steers. J. Anim. Sci. 90, 3574-3583.

Benedeti, P.D.B., Paulino, P.V.R., Marcondes, M.I., Valadares Filho, S.C., Martins, T.S., Lisboa, E.F., Silva, L.H.P., Teixeira, C.R.V., Duarte, M.S., 2014. Soybean meal replaced by slow release urea in finishing diets for beef cattle. Livest. Sci. 165, 51-60.

Bierman, S., Erickson, G.E., Klopfenstein, T.J., Stock, R.A., Shain, D.H., 1999. Evaluation of nitrogen and organic matter balance in the feedlot as affected by level and source of dietary fiber. J. Anim. Sci. 77, 1645-1653.

Brake, D.W., Titgemeyer, E.C., Jones, M.L., Anderson, D.E., 2010. Effect of nitrogen supplementation on urea kinetics and microbial use of recycled urea in steers consuming corn-based diets. J. Anim. Sci. 88, 2729-2740. 
Browne, E.M., Juniper, D.T., Bryant, M.J., Beever, D.E., 2005. Apparent digestibility and nitrogen utilisation of diets based on maize and grass silage fed to beef steers. Anim. Feed Sci. Technol. 119, 55-68.

Bunting, L.D., Boling, J.A., MacKown, C.T., 1989. Effect of dietary protein level on nitrogen metabolism in the growing bovine: I. nitrogen recycling and intestinal protein supply in calves. J. Anim. Sci. 67, 810-819.

Buttrey, E.K., Cole, N.A., Jenkins, K.H., Meyer, B.E., McCollum, I.F.T., Preece, S.L.M., Auvermann, B.W., Heflin, K.R., MacDonald, J.C., 2012. Effects of twenty percent corn wet distillers grains plus solubles in steam-flaked and dry-rolled corn-based finishing diets on heifer performance, carcass characteristics, and manure characteristics. J. Anim. Sci. 90, 5086-5098.

Cheng, L., Judson, H.G., Bryant, R.H., Mowat, H., Guinot, L., Hague, H., Taylor, S., Edwards, G.R., 2017. The effects of feeding cut plantain and perennial ryegrass-white clover pasture on dairy heifer feed and water intake, apparent nutrient digestibility and nitrogen excretion in urine. Anim. Feed Sci. Technol. 229, 43-46.

Cole, N.A., Greene, L.W., McCollum, F.T., Montgomery, T., McBride, K., 2003. Influence of oscillating dietary crude protein concentration on performance, acid-base balance, and nitrogen excretion of steers. J. Anim. Sci. 81, 2660-2668.

Devant, M., Ferret, A., Gasa, J., Calsamiglia, S., Casals, R., 2000. Effects of protein concentration and degradability on performance, ruminal fermentation, and nitrogen metabolism in rapidly growing heifers fed high-concentrate diets from 100 to $230 \mathrm{~kg}$ body weight. J. Anim. Sci. 78, 1667-1676.

Drewnoski, M.E., Poore, M.H., 2012. Effects of supplementation frequency on ruminal fermentation and digestion by steers fed medium-quality hay and supplemented with a soybean hull and corn gluten feed blend. J. Anim. Sci. 90, 881-891. 
Fiems, L.O., Cottyn, B.G., Boucqué, C.V., Bogaerts, D.F., Eenaeme, C., Vanacker, J.M., 1997. Effect of beef type, body weight and dietary protein content on voluntary feed intake, digestibility, blood and urine metabolites and nitrogen retention. J. Anim. Physiol. Anim. Nutr. 77, 1-9.

Funaba, M., Kagiyama, K., Iriki, T., Abe, M., 1997. Duodenal flow of microbial nitrogen estimated from urinary excretion of purine derivatives in calves after early weaning. J. Anim. Sci. 75, 1965-1973.

Gabler, M.T., Heinrichs, A.J., 2003. Altering soluble and potentially rumen degradable protein for prepubertal holstein heifers. J. Dairy Sci. 86, 2122-2130.

Giri, S.S., Sahoo, A., Pathak, N.N., 2000. Feed intake, digestibility, plane of nutrition and live weight gain by crossbred growing bulls fed on grainless diets containing different nitrogen sources. Anim. Feed Sci. Technol. 83, 195-203.

Hales, K.E., Cole, N.A., MacDonald, J.C., 2012. Effects of corn processing method and dietary inclusion of wet distillers grains with solubles on energy metabolism, carbon-nitrogen balance, and methane emissions of cattle. J. Anim. Sci. 90, 3174-3185.

Hales, K.E., Jaderborg, J.P., Crawford, G.I., DiCostanzo, A., Spiehs, M.J., Brown-Brandl, T.M., Freetly, H.C., 2015. Effects of dry-rolled or high-moisture corn with twenty-five or forty-five percent wet distillers' grains with solubles on energy metabolism, nutrient digestibility, and macromineral balance in finishing beef steers. J. Anim. Sci. 93, 49955005.

Hankins, S.L., Arseneau, J.D., Lemenager, R.P., Sutton, A.L., 2005. Performance, carcass traits, and nutrient excretion of beef feedlot cattle fed a corn gluten feed diet. Prof. Anim. Sci. 21, 1-6. 
Hill, G.M., Newton, G.L., Streeter, M.N., Hanna, W.W., Utley, P.R., Mathis, M.J., 1996. Digestibility and utilization of pearl millet diets fed to finishing beef cattle. J. Anim. Sci. 74, 1728-1735.

Hill, G.M., Utley, P.R., 1989. Digestibility, protein metabolism and ruminal degradation of beagle 82 triticale and kline barley fed in corn-based cattle diets. J. Anim. Sci. 67, 17931804.

Hill, G.M., West, J.W., 1991. Rumen protected fat in kline barley or corn diets for beef cattle: digestibility, physiological, and feedlot responses. J. Anim. Sci. 69, 3376-3388.

Hoffman, P.C., Esser, N.M., Bauman, L.M., Denzine, S.L., Engstrom, M., Chester-Jones, H., 2001. Short communication: effect of dietary protein on growth and nitrogen balance of Holstein heifers. J. Dairy Sci. 84, 843-847.

Holder, V.B., El-Kadi, S.W., Tricarico, J.M., Vanzant, E.S., McLeod, K.R., Harmon, D.L., 2013. The effects of crude protein concentration and slow release urea on nitrogen metabolism in Holstein steers. Arch. Anim. Nutr. 67, 93-103.

Holder, V.B., Tricarico, J.M., Kim, D.H., Kristensen, N.B., Harmon, D.L., 2015. The effects of degradable nitrogen level and slow release urea on nitrogen balance and urea kinetics in Holstein steers. Anim. Feed Sci. Technol. 200, 57-65.

Hosoda, K., Miyaji, M., Matsuyama, H., Imai, Y., Nonaka, K., 2012. Digestibility, ruminal fermentation, nitrogen balance and methane production in Holstein steers fed diets containing soy sauce cake at 10 or $20 \%$. Anim. Sci. J. 83, 220-226.

Hünerberg, M., McGinn, S.M., Beauchemin, K.A., Okine, E.K., Harstad, O.M., McAllister, T.A., 2013a. Effect of dried distillers grains plus solubles on enteric methane emissions and nitrogen excretion from growing beef cattle. J. Anim. Sci. 91, 2846-2857.

Hünerberg, M., McGinn, S.M., Beauchemin, K.A., Okine, E.K., Harstad, O.M., McAllister, T.A., 2013b. Effect of dried distillers' grains with solubles on enteric methane 
emissions and nitrogen excretion from finishing beef cattle. Can. J. Anim. Sci. 93, 373385.

James, T., Meyer, D., Esparza, E., Depeters, E.J., Perez-Monti, H., 1999. Effects of dietary nitrogen manipulation on ammonia volatilization from manure from Holstein heifers. J. Dairy Sci. 82, 2430-2439.

Jiao, H.P., Yan, T., McDowell, D.A., 2014. Prediction of manure nitrogen and organic matter excretion for young Holstein cattle fed on grass silage-based diets. J. Anim. Sci. 92, $3042-3052$.

Johnson, J.M., Shreck, A.L., Nuttelman, B.L., Burken, D.B., Erickson, G.E., Rincker, M.J., Cecava, M.J., Klopfenstein, T.J., 2015. Effects of twenty percent alkaline-treated corn stover without or with yucca extract on performance and nutrient mass balance of finishing steers fed modified distillers grains-based diets. J. Anim. Sci. 93, 3034-3043.

Kazemi-Bonchenari, M., Salem, A.Z.M., Ghasemi, E., 2016. Effect of urea supplementation in diet based on barley grain or corn silage on performance, digestion, rumen fermentation and microbial protein synthesis in Holstein bull calves. Indian J. Anim. Sci. 86, 313317.

Kegley, E.B., Harvey, R.W., Spears, J.W., 1991. Effects of lysocellin and calcium level on mineral metabolism, performance and ruminal and plasma characteristics of beef steers. J. Anim. Sci. 69, 782-791.

Kim, S.C., Adesogan, A.T., Arthington, J.D., 2007. Optimizing nitrogen utilization in growing steers fed forage diets supplemented with dried citrus pulp. J. Anim. Sci. 85, 25482555.

Kluth, H., Gabel, M., Voigt, J., Schönhusen, U., 2000. The use of endogenous nitrogen for microbial crude protein synthesis in the rumen of growing bulls. J. Anim. Physiol. Anim. Nutr. 84, 136-147. 
Knaus, W.F., Beermann, D.H., Guiroy, P.J., Boehm, M.L., Fox, D.G., 2001. Optimization of rate and efficiency of dietary nitrogen utilization through the use of animal by-products and(or) urea and their effects on nutrient digestion in Holstein steers. J. Anim. Sci. 79, 753-760.

Knaus, W.F., Beermann, D.H., Robinson, T.F., Fox, D.G., Finnerty, K.D., 1998. Effects of a dietary mixture of meat and bone meal, feather meal, blood meal, and fish meal on nitrogen utilization in finishing Holstein steers. J. Anim. Sci. 76, 1481-1487.

Knaus, W.F., Beermann, D.H., Tedeschi, L.O., Czajkowski, M., Fox, D.G., Russell, J.B., 2002. Effects of urea, isolated soybean protein and blood meal on growing steers fed a cornbased diet. Anim. Feed Sci. Technol. 102, 3-14.

Koenig, K.M., Beauchemin, K.A., 2013a. Nitrogen metabolism and route of excretion in beef feedlot cattle fed barley-based backgrounding diets varying in protein concentration and rumen degradability. J. Anim. Sci. 91, 2295-2309.

Koenig, K.M., Beauchemin, K.A., 2013b. Nitrogen metabolism and route of excretion in beef feedlot cattle fed barley-based finishing diets varying in protein concentration and rumen degradability. J. Anim. Sci. 91, 2310-2320.

Krehbiel, C.R., Kreikemeier, K.K., Ferrell, C.L., 2000. Influence of Bos indicus crossbreeding and cattle age on apparent utilization of a high-grain diet. J. Anim. Sci. 78, 1641-1647.

Lascano, G.J., Velez, M., Tricarico, J.M., Heinrichs, A.J., 2012. Short communication: Nutrient utilization of fresh sugarcane-based diets with slow-release nonprotein nitrogen addition for control-fed dairy heifers. J.Dairy Sci. 95, 370-376.

Lee, C., Araujo, R.C., Koenig, K.M., Beauchemin, K.A., 2015. Effects of encapsulated nitrate on enteric methane production and nitrogen and energy utilization in beef heifers. J. Anim. Sci. 93, 2391-2404. 
Li, Y.L., Beauchemin, K.A., McAllister, T.A., Yang, W.Z., 2014. Intakes and excretion route of nitrogen, phosphorous and sulfur by finishing beef heifers fed increasing levels of wheat dried distillers grains with solubles to substitute for barley grain and barley silage. Livest. Sci. 170, 43-52.

Luebbe, M.K., Patterson, J.M., Jenkins, K.H., Buttrey, E.K., Davis, T.C., Clark, B.E., McCollum, I.F.T., Cole, N.A., MacDonald, J.C., 2012. Wet distillers grains plus solubles concentration in steam-flaked-corn-based diets: Effects on feedlot cattle performance, carcass characteristics, nutrient digestibility, and ruminal fermentation characteristics. J. Anim. Sci. 90, 1589-1602.

Marini, J.C., Van Amburgh, M.E., 2003. Nitrogen metabolism and recycling in Holstein heifers. J. Anim. Sci. 81, 545-552.

Matthews, A.K., Poore, M.H., Huntington, G.B., Green, J.T., 2005. Intake, digestion, and N metabolism in steers fed endophyte-free, ergot alkaloid-producing endophyte-infected, or nonergot alkaloid-producing endophyte-infected fescue hay. J. Anim. Sci. 83, 11791185.

McGuire, D.L., Bohnert, D.W., Schauer, C.S., Falck, S.J., Cooke, R.F., 2013. Daily and alternate day supplementation of urea or soybean meal to ruminants consuming lowquality cool-season forage: I-Effects on efficiency of nitrogen use and nutrient digestion. Livest. Sci. 155, 205-213.

Menezes, A.C.B., Valadares Filho, S.C., Costa e Silva, L.F., Pacheco, M.V.C., Pereira, J.M.V., Rotta, P.P., Zanetti, D., Detmann, E., Silva, F.A.S., Godoi, L.A., Rennó, L.N., 2016. Does a reduction in dietary crude protein content affect performance, nutrient requirements, nitrogen losses, and methane emissions in finishing Nellore bulls? Agric. Ecosyst. Environ. 223, 239-249. 
Osuji, P.O., Khalili, H., 1994. The effect of replacement of wheat bran by graded levels of molasses on feed intake, organic matter digestion, rumen fermentation and nitrogen utilization in crossbred (Bos taurus $\times$ Bos indicus) steers fed native grass hay. Anim. Feed Sci. Technol. 48, 153-163.

Piñeiro-Vázquez, A.T., Jiménez-Ferrer, G.O., Chay-Canul, A.J., Casanova-Lugo, F., DíazEcheverría, V.F., Ayala-Burgos, A.J., Solorio-Sánchez, F.J., Aguilar-Pérez, C.F., KuVera, J.C., 2017. Intake, digestibility, nitrogen balance and energy utilization in heifers fed low-quality forage and Leucaena leucocephala. Anim. Feed Sci. Technol. 228, 194201.

Rouzbehan, Y., Galbraith, H., Topps, J.H., Rooke, J., 1996. Response of growing steers to diets containing big bale silage and supplements of molassed sugar beet pulp with and without white fish meal. Anim. Feed Sci. Technol. 62, 151-162.

Sahoo, A., Chaudhary, L.C., Agarwal, N., Kamra, D.N., Pathak, N.N., 2000. Effect of feeding different ratios of green fodder and straw supplemented with wheat bran on the performance of male crossbred calves. Asian-Australas. J. Anim. Sci. 13, 19-22.

Sayer, K.M., Buckner, C.D., Erickson, G.E., Klopfenstein, T.J., Macken, C.N., Loy, T.W., 2013. Effect of corn bran and steep inclusion in finishing diets on diet digestibility, cattle performance, and nutrient mass balance. J. Anim. Sci. 91, 3847-3858.

Seo, J.K., Yang, J., Kim, H.J., Upadhaya, S.D., Cho, W.M., Ha, J.K., 2010. Effects of synchronization of carbohydrate and protein supply on ruminal fermentation, nitrogen metabolism and microbial protein synthesis in Holstein steers. Asian-Australas. J. Anim. Sci. 23, 1455-1461.

Spiehs, M.J., Varel, V.H., 2009. Nutrient excretion and odorant production in manure from cattle fed corn wet distillers grains with solubles. J. Anim. Sci. 87, 2977-2984. 
Stobo, I.J.F., Roy, J.H.B., 2007. The protein requirement of the ruminant calf: 4. Nitrogen balance studies on rapidly growing calves given diets of different protein content. Br. J. Nutr. 30, 113-125.

Taylor-Edwards, C.C., Elam, N.A., Kitts, S.E., McLeod, K.R., Axe, D.E., Vanzant, E.S., Kristensen, N.B., Harmon, D.L., 2009. Influence of slow-release urea on nitrogen balance and portal-drained visceral nutrient flux in beef steers. J. Anim. Sci. 87, 209221.

Theurer, C.B., Huntington, G.B., Huber, J.T., Swingle, R.S., Moore, J.A., 2002. Net absorption and utilization of nitrogenous compounds across ruminal, intestinal, and hepatic tissues of growing beef steers fed dry-rolled or steam-flaked sorghum grain. J. Anim. Sci. 80, $525-532$.

Valkeners, D., Théwis, A., Van Laere, M., Beckers, Y., 2008. Effect of rumen-degradable protein balance deficit on voluntary intake, microbial protein synthesis, and nitrogen metabolism in growing double-muscled Belgian Blue bulls fed corn silage-based diet. J. Anim. Sci. 86, 680-690.

Vasconcelos, J.T., Cole, N.A., McBride, K.W., Gueye, A., Galyean, M.L., Richardson, C.R., Greene, L.W., 2009. Effects of dietary crude protein and supplemental urea levels on nitrogen and phosphorus utilization by feedlot cattle. J. Anim. Sci. 87, 1174-1183.

Walter, L.J., McAllister, T.A., Yang, W.Z., Beauchemin, K.A., He, M., McKinnon, J.J., 2012. Comparison of wheat or corn dried distillers grains with solubles on rumen fermentation and nutrient digestibility by feedlot heifers. J. Anim. Sci. 90, 1291-1300.

Wray, M.I., Beeson, W.M., Perry, T.W., 1980. Effect of soybean, feather and hair meal protein on dry matter, energy and nitrogen utilization by growing steers. J. Anim. Sci. 50, 581589. 
Zanton, G.I., Gabler, M.T., Heinrichs, A.J., 2007. Manipulation of soluble and rumenundegradable protein in diets fed to postpubertal dairy heifers. J. Dairy Sci. 90, 978986.

Zanton, G.I., Heinrichs, A.J., 2009. Digestion and nitrogen utilization in dairy heifers limit-fed a low or high forage ration at four levels of nitrogen intake. J. Dairy Sci. 92, 2078-2094.

Zanton, G.I., Heinrichs, A.J., 2016. Efficiency and rumen responses in younger and older Holstein heifers limit-fed diets of differing energy density. J. Dairy Sci. 99, 2825-2836. 